The Costs, Wealth Effects, and Determinants of International Capital Raising: Evidence from Public Yankee Bonds

By: Darius P. Miller and John J. Puthenpurackal

William Davidson Working Paper Number 445

October 2001 


\title{
The Costs, Wealth Effects, and Determinants of International Capital Raising: Evidence from Public Yankee Bonds
}

\author{
By Darius P. Miller ${ }^{a}$ and John J. Puthenpurackal ${ }^{b^{*}}$
}

\author{
${ }^{a}$ Kelley School of Business, Indiana University, 1309 E. Tenth Street, Bloomington, IN 47405, Phone: \\ 812.855.3395email: damiller@indiana.edu \\ ${ }^{\mathrm{b}}$ Lowry Mays College and Graduate School of Business, Texas A\&M University, College Station, TX \\ 77843-4218, Phone: 979.845.4895 Fax: 979.845.3884 email: pjohn@cgsb.tamu.edu
}

Current version: October 2001

\begin{abstract}
This paper examines the costs, wealth effects, and determinants of international capital raising for a sample of 260 public debt issues made by non-U.S. firms in the U.S. (Yankee) market. We find that investors demand economically significant premiums on bonds issued by firms that are located in countries that do not protect investors' rights and do not have a prior history of on-going disclosure. The results provide support for the literature that suggests better legal protections and more detailed information disclosure increases the price investors will pay for financial assets. We also find that the average stock price reaction to Yankee bond offerings is significantly positive and that abnormal returns are largest for first-time Yankee bond issuers. In addition, we show that foreign firms tend to issue in the Yankee market when the relative interest cost is low, indicating that potential differences in borrowing costs influence where firms choose to sell bonds.
\end{abstract}

Key words: Yankee bonds, International Capital Raising

JEL classification: F3

Please address all correspondence to:

Darius P. Miller

Kelley School of Business

Indiana University

1309 E. Tenth St.

Bloomington, IN 47405

(812) 855-3395

(812) 855-5875 (fax)

damiller@indiana.edu

\footnotetext{
${ }^{*}$ We would like to thank Arturo Bris, Vihang Errunza, Steve Foerster, Philippe Jorion, Joshua Coval, Karl Lins, Mike Weisbach, Marc Zenner and seminar participants at the Sixth International Finance Conference at Georgia Tech University, the 2001 EFA Meetings, the William Davidson Institute/Journal of Financial Intermediation Conference on Banking in Emerging Markets, University of Virginia Darden School, Georgetown University, Indiana University, Texas A\&M University, Texas Tech University, Tulane University, Wake Forest University and the World Bank for helpful comments and suggestions. Hwan Shin provided valuable assistance with the data. We especially thank Laura Field and Ro Gutierrez for suggestions that have improved the quality of the paper. We also thank the Center for International Business Studies at Texas A\&M University for financial support.
} 


\section{William Davidson Institute Working Paper 445}

\section{Non-Technical Summary}

Over the last decade, there has been remarkable growth in public debt offerings in the U.S. by foreign firms. These issues, known as "Yankee bonds", provide a major source of external capital for non-U.S. firms and play an important role in the development of international capital markets. In 1998 alone, overseas firms raised over $\$ 51$ billion in public bonds in the U.S., a greater than tenfold increase from 1988. Equity issues by foreign firms in the U.S., while the focus of much attention, have not raised nearly this amount of capital.

Using a sample of 260 Yankee bonds from 16 countries, we find that investors require economically significant premiums for bonds issued by firms located in countries with poor investor protections. For example, moving from a country like Mexico that has relatively weak creditor protections and legal systems to a country like the United Kingdom that has relatively strong laws and enforcement decreases the annual yield spread of public corporate bonds by 58 basis points, ceteris paribus. Our results also show that investors demand premiums on the bonds of first-time issuers. We find that public borrowing costs are lowered by 41 basis points when a firm has listed or issued public securities in the U.S. prior to the debt offering. This reduction in public borrowing costs exists for both prior public debt issues (Yankee bonds) and prior stock cross-listings (ADRs or direct listings), and is largest in noninvestment-grade securities. Overall, our results provide support for the literature that suggests better legal protections and more detailed information disclosure increase the price investors will pay for financial assets, ceteris paribus.

We next investigate the wealth effects associated with Yankee bond offerings. We find positive and significant abnormal returns around the announcement date, providing evidence that firms benefit from raising public debt in the United States We also find that the stock price reaction is largest for firsttime issuers, consistent with the hypotheses that issuing or listing in the U.S. signals, widens the firm's investor base, or both. 
Finally, our analysis provides new insights into why foreign firms choose a particular market to raise debt capital and how relative interest costs drive the decision. We explicitly model the joint determination of interest costs and market choice (Yankee versus Euro) using a switching regression model with endogenous switching. In this way, we construct a unified framework in which the determinants of interest costs and the choice of market are jointly estimated. We find that one of the main factors that influences where a firm sells bonds is the relative interest costs between markets. Firms tend to issue in the Yankee market when the relative interest cost in the Yankee market is low, indicating that potential differences in borrowing costs influence where firms choose to sell bonds. 


\section{William Davidson Institute Working Paper 445}

\section{Introduction}

Over the last decade, there has been remarkable growth in public debt offerings in the U.S. by foreign firms. These issues, known as "Yankee bonds", provide a major source of external capital for non-U.S. firms and play an important role in the development of international capital markets. In 1998 alone, overseas firms raised over $\$ 51$ billion in public bonds in the U.S., a greater than tenfold increase from 1988. Equity issues by foreign firms in the U.S., while the focus of much attention, have not raised nearly this amount of capital.

The U.S. corporate bond market is unparalleled in both its size and scope. Its large, sophisticated investor base allows overseas corporations the ability to issue bonds of various maturities and credit risks. For example, long-term/below-investment-grade corporate bonds are essentially exclusive to the U.S. corporate bond market. In contrast, strict government regulations and narrow investor bases have caused the domestic public bond markets in non-U.S. countries to remain a relatively limited source of external firm financing (Fabozzi, 1997: Giddy 1994). The Yankee bond market provides foreign firms with unique financing opportunities unavailable elsewhere in the world. Despite its significance, virtually no studies examine this important market. To fill this gap, our paper pursues two objectives. First, we provide evidence on how public Yankee bonds are priced, how their issuance affects shareholder value, and how relative interest costs drive the issuance decision. Second, we exploit the Yankee market data to measure the effects of legal protections and information disclosure on asset prices, since firms issuing in the Yankee market come from a wide range of countries with large differences in legal and information environments.

We first examine the pricing of Yankee bonds. Investors are, in general, less likely to be familiar with foreign issuers and more uncertain regarding the protection of their rights. We recognize this in our analysis of Yankee bond pricing in order to measure the effects of country and firm specific factors that have been argued to affect how investors price risk. We are motivated by the numerous studies that link capital market development with country-specific legal institutions (La Porta et al. (LLSV), 1997, 1998, 


\section{William Davidson Institute Working Paper 445}

1999). This literature suggests that the level of capital market development is positively related to the extent that investor's rights are protected. Protection is defined not only by the rights written into laws and regulations but also by their enforcement. In this view, securities laws, judicial systems, and disclosure requirements that better protect creditor rights should increase the price investors are willing to pay for securities.

Our analysis of Yankee bond pricing provides new evidence on how investor protections directly affect asset prices. By focusing on individual bond issues, we abstract away from the potential problems of market-level studies raised by Rajan and Zinagles (1998). They argue that cross-country differences in industrial composition can cause a spurious relationship between external finance and investor protections. Using individual bonds also allows us to control for risk when measuring the effects of legal protections, a point emphasized by Lombardo and Pagano (2000). Our bond market evidence complements their firm-level stock return analysis. Our findings also have important policy implications when viewed as a measure of the costs that countries with poor investor protections impose on their firms.

The analysis of Yankee bond pricing also provides insights on the role of reputation and information availability in the pricing of public debt. Differences in securities laws, judicial systems, accounting standards, disclosure requirements, cultures and languages may serve to increase the information asymmetry between U.S. investors and foreign borrowers. If investors require a premium for this uncertainty, firms may benefit from actions that certify they will act in the interest of U.S. investors. Coffee (1999), La Porta (1999), and Stulz (1999) argue one way firms can reduce this uncertainty is by cross-listing or issuing public equity in the United States. ${ }^{1}$ A U.S. cross-listing is a commitment to ongoing SEC information disclosure. Consistent with this hypothesis, Fenn (2000) and Chaplinsky and Ramchand (2000) find evidence that investors value increased disclosure. In addition, cross-listing equity increases analyst coverage and visibility of the firm, which may also increase information availability (Baker, Nofsinger, and Weaver, 1999). Diamond (1989) suggests that another approach foreign firms can 


\section{William Davidson Institute Working Paper 445}

take to assure creditors in the U.S. is to establish a borrowing history with U.S. investors. In this way, borrowers deliver on their contracts not because they are forced to but because doing so builds a good reputation that facilitates future access to capital markets at favorable terms. Also, once a firm has issued debt in the U.S. market, it is likely to provide credit analysts with relevant information on an on-going basis. If a good reputation and better information availability are important, investors will, ceteris paribus, pay more for the Yankee bonds of firms that had (i) previously issued debt in the U.S. market and (ii) cross-listed equity on U.S. markets, prior to the Yankee bond offering.

Using a sample of 260 Yankee bonds from 16 countries, we find that investors require economically significant premiums for bonds issued by firms located in countries with poor investor protections. For example, moving from a country like Mexico that has relatively weak creditor protections and legal systems to a country like the United Kingdom that has relatively strong laws and enforcement decreases the annual yield spread of public corporate bonds by 58 basis points, ceteris paribus. Our results also show that investors demand premiums on the bonds of first-time issuers. We find that public borrowing costs are lowered by 41 basis points when a firm has listed or issued public securities in the U.S. prior to the debt offering. This reduction in public borrowing costs exists for both prior public debt issues (Yankee bonds) and prior stock cross-listings (ADRs or direct listings), and is largest in noninvestment-grade securities. Overall, our results provide support for the literature that suggests better legal protections and more detailed information disclosure increase the price investors will pay for financial assets, ceteris paribus.

We next investigate the wealth effects associated with Yankee bond offerings. We find positive and significant abnormal returns around the announcement date, providing evidence that firms benefit from raising public debt in the United States. This result is similar to the results of Kim and Stulz (1988) who find that the stock market reacts positively to U.S. firms issuing in the offshore Eurobond market. While the positive wealth effects stand in contrast to the non-positive reaction found for U.S. firms

\footnotetext{
${ }^{1}$ Foreign firms can use existing shares or sell new equity to cross-list on U.S. public markets. Since they are
} 


\section{William Davidson Institute Working Paper 445}

issuing public debt in the U.S. (Eckbo, 1986), our event study results on Yankee bond issues adds to recent work by Kang, Kim, Park, and Stulz (1995), Errunza and Miller (1999), and Chaplinsky and Ramchand (1999). In these studies, offshore equity issues are found to have larger stock price reactions than domestic equity offerings by U.S. firms. We also find that the stock price reaction is largest for firsttime issuers, consistent with the hypotheses that issuing or listing in the U.S. signals quality (Stulz, 1999, Cantale, 1998, Fuerst, 1998), widens the firm's investor base (Merton, 1987), or both. This new information would be relevant to shareholders as well as bondholders.

Finally, our analysis provides new insights into why foreign firms choose a particular market to raise debt capital and how relative interest costs drive the decision. We explicitly model the joint determination of interest costs and market choice (Yankee versus Euro) using a switching regression model with endogenous switching. In this way, we construct a unified framework in which the determinants of interest costs and the choice of market are jointly estimated. We find that one of the main factors that influences where a firm sells bonds is the relative interest costs between markets. Firms tend to issue in the Yankee market when the relative interest cost in the Yankee market is low, indicating that potential differences in borrowing costs influence where firms choose to sell bonds. This finding is consistent with the results of Kim and Stulz (1988) who find that potential borrowing costs are an important factor driving firms to issue bonds outside their home market. In a test of this clientele hypothesis, they show that shareholder wealth is increased for Eurodollar bond offerings by U.S. firms when the domestic and Euro interest cost spread is largest. ${ }^{2}$

The remainder of the paper is organized as follows. Section 2 gives an overview of the Yankee bond market, while Section 3 describes the data set used in the paper. Section 4 examines the effects of country specific legal institutions and firm specific factors on public debt costs, and Section 5 investigates

\footnotetext{
functionally equivalent for our analysis, we refer to both as cross-listings.

${ }^{2}$ For evidence on the yield differential between the U.S. domestic and Eurodollar market, see Finnerty, Schneeweis, and Hedge (1980), Finnerty and Nunn (1985), Finnerty (1985), Kidwell, Marr, and Thompson (1985), Mahajan and Fraser (1986), Kidwell, Marr, and Trimble (1987).
} 


\section{William Davidson Institute Working Paper 445}

the stock price reaction to a Yankee bond offering. Section 6 examines how relative interest costs influence the decision to issue Yankee bonds, and a summary is given in Section 7.

\section{The Yankee bond market}

Yankee bonds were first issued in the early 1900s as a means for overseas borrowers to raise capital in the United States. The Yankee bond market is comprised of foreign domiciled issuers who register with the SEC and borrow dollars for delivery in the U.S. using a U.S. syndicate to underwrite the issue. One defining feature of the Yankee market is the level of registration and disclosure requirements. Foreign domiciled issuers of Yankee bonds must adhere to similar regulations as U.S. firms, namely the U.S. Securities Act of 1933 and the Exchange Act of 1934. Therefore, Yankee bonds must be registered bonds, with the owner's name recorded by the issuer. In addition, the issuer must provide a prospectus disclosing detailed financial information that often is more extensive than required in its home country. The regulations can result in increased costs, add time needed to bring the issue to market, and disclose information that the issuer would like to keep confidential.

While the Yankee bonds afford U.S. investors some protections that they would not receive if they bought bonds issued by foreign firms in their local market, it is important to note that they do not grant investors the same rights as when they invest in the bonds of U.S. corporations. Both La Porta et al. (1999) and Kim and Stulz (1988) note that there are limitations of this opt-in (cross-listing) mechanism, particularly in the case of creditor rights. For example, the enforceability of the bond indentures first requires the determination of what laws apply and what court is to be used. In addition, assets located in a particular country generally remain under the jurisdiction of that country's laws. Therefore, when a claim has been settled, collection may depend on the amount of assets the foreign firm has in the United States. These limitations render the firm's home market legal environment relevant to U.S. investors.

Yankee bonds have several potential advantages for overseas firms seeking to raise new capital.

Outside the U.S., domestic public bond markets have not been a major source of external firm financing 


\section{William Davidson Institute Working Paper 445}

(Fabozzi, 1997; Giddy, 1994). Many countries have discouraged private-sector bonds in favor of bank loans or equity financing. For example, before 1980 Japanese firms were prohibited from raising debt in domestic public markets. Until very recently, Japanese firms still faced many constraints on public bond issuance. These included a time-consuming queuing system, fixed underwriting fees, fixed pricing systems, and strict limits on what types of firms may issue. Even in countries without significant government restrictions on debt issues, the demand for anything other than short to medium-term investment-grade debt has been low. ${ }^{3}$ Therefore, the Yankee bond market provides non-U.S. firms an avenue for raising public debt that is often unavailable in their own domestic market. By adhering to the regulations of the U.S. market, foreign issuers can benefit from access to the largest and most liquid of the world's bond markets. Life insurance companies and pension funds are major investors in U.S. corporate bonds and have historically purchased long-term debt instruments to match their long-term liabilities. Therefore, the Yankee market provides an opportunity for foreign borrowers to arrange long-term financing, which is uncommon in most non-U.S. domestic and offshore bond markets (Karolyi and Johnston, 1998).

While Yankee bonds were first issued in the early 1900s, the market has experienced dramatic growth over the last decade. Figure 1 shows the history of capital raised in the U.S. by foreign firms, including public debt (Yankee bonds), public equity (ADRs or direct offerings), and privately placed debt (foreign 144a bonds). ${ }^{4}$ One striking feature is the dramatic increase in the amount of capital raised by all forms of securities. For example, Yankee bonds increased from $\$ 3.2$ billion in 1988 to almost $\$ 50$ in 1998. We also see that the volume of equity offerings do not reach the volume levels of debt, either public or private.

Figure 2 compares the public debt raised by non-U.S. firms in the U.S. and the Eurobond markets. The Eurobond market is the largest market for non-U.S. firms to raise public corporate debt. Eurobonds are bonds that are issued and traded outside the jurisdiction of any single country. Eurobonds

\footnotetext{
${ }^{3}$ See Jacquie MacNish, "Canadian Firms Crack U.S. Junk Bond Market”, The Globe and Mail Report on Business,
} 


\section{William Davidson Institute Working Paper 445}

are issued in different currency denominations, but bonds issued in U.S. dollars (Eurodollar bonds) have been historically the largest single component of the market. While the first Eurodollar bond was issued in 1963, Figure 2 shows that their use as a major international capital-raising tool has been a recent phenomenon. By 1998, the volume of public corporate debt issued by foreign firms in the Yankee market was approximately one-sixth of that raised in the Eurobond market (\$49.9 Billion versus $\$ 296.3$ billion). If we consider only dollar-denominated Eurobonds, the Yankee market was approximately one-half the size of the Eurodollar market in 1998 ( $\$ 49.9$ billion versus $\$ 94.8$ billion).

Table I provides additional information on the composition of the Yankee market. Financial corporations have been the most predominant Yankee issuers, followed by industrial corporations and utilities. Canadian firms have historically issued a majority of the bonds in the Yankee market, but have recently been overtaken in terms of volume by European firms. Issues by Asian and Latin American firms also have increased substantially in volume during the 1990s. Table I also shows that while the Yankee market has been dominated by investment-grade securities, there also exists substantial volume in high-yield bond issues (24\% over the 1992-1995 period).

\section{The Data}

Our sample consists of 260 fixed-rate corporate Yankee bonds issued by firms domiciled outside the U.S. from 1987 to 1998 . We use Securities Data Corporation, Inc. (SDC) as our primary source to select our sample and obtain issue characteristics. The characteristics necessary to compute the issue yield (offer price, coupon payments and maturity) must be identifiable from SDC to be included in the sample. We compute the yields of the bonds given the bond details from SDC and cross-check our computed yields with that given by SDC. We exclude issues by financials, sovereigns, and supranationals as well as issues with conversion features or variable-rate coupons. We use the credit rating of Moody's

July 11, 1994, pp. B1,B3.

${ }^{4}$ 144a refers to SEC Rule 144a that governs secondary trading in privately placed securities. 


\section{William Davidson Institute Working Paper 445}

whenever it is available and use the S\&P rating in the few cases where only an S\&P rating was available. All the corporate Yankee bonds are denominated in U.S. dollars.

We obtain other details about our bond issues, such as date of issuance, the size of the issue, presence of call or sinking funds provisions, and seniority from SDC. SDC data also allow us to determine if a particular issue was the firm's first Yankee debt issue in the United States. After talking with SDC officials, we found that the last digit of the SDC firm identifier for a particular firm may change over time. Hence, to check whether an issuer had a previous Yankee debt issue, we use a truncated SDC identifier for matching purposes. The SDC database does not give us all the information necessary to determine which companies had previously listed equity in the United States. For this purpose, we augment the information that SDC compiles on equity offerings in the U.S. with information on foreign firm cross-listings (non-capital raising) supplied from the CRSP tapes and from information provided by the Bank of New York.

Table II provides summary characteristics of the sample by years, location of issuer, broad industries, and sample statistics. The sample consists of 260 Yankee bond issues from 16 countries. The increasing frequency of Yankee issues is evident from Panel A: 10 issues are found in the first three years of the sample compared to 119 in the last three years. Panel B shows that Canadian firms (151) were the most frequent issuers over our sample period, followed by Europe (53), Latin America (32), and Asia (24). Panel $\mathrm{C}$ shows that issuers are from different industries and there is no evidence of concentration in any particular industry. Manufacturing (97), Communications (32), Utilities (41), Mining, Construction, and Agriculture (64) and Transport, Trade and Services (27) is the broad industry breakdown of the sample. Panel D gives some sample statistics. The mean years to maturity of the sample is 14.5 years and mean issue size is $\$ 214.8$ million. Investment grade issues comprise about $75 \%$ of our sample. About $59 \%$ of issues had a prior U.S. equity cross-listing and $48 \%$ had a previous public debt offer. About $75 \%$ of the sample had either a prior equity cross-listing or a previous public debt offer. 


\section{William Davidson Institute Working Paper 445}

\section{Yankee bond pricing}

In this section, we focus on Yankee bond pricing to measure the effects of investor protections and information disclosure on bond prices. We follow previous studies that suggest the yield on new issues of public debt can be determined by default risk, the maturity of the issue, issue size, the presence of call and/or sinking fund provisions, and general economic conditions at the time of the sale (see, e.g., Ederington, 1975, Kidwell, Marr, and Thompson, 1985, and Blackwell and Kidwell, 1988). We examine the determinants of bond pricing using multivariate models that employ the at-issue yield spread as the dependent variable. ${ }^{5}$ The yield spread is calculated as the difference between the at-issue yield for the Yankee debt offer and the yield of a Treasury bond with similar maturity. When an exact match is not available, we interpolate between the two closest maturity matches. To calculate the bond's yield, we use the net proceeds of the offering (net of underwriting and other issue costs). The independent variables include country and firm-specific test variables as well as control variables. The model is estimated using the following Ordinary Least Squares regression (standard errors are corrected for heteroskedasticity using White's (1980) procedure):

$$
\begin{aligned}
& \text { YLDSPD } \\
& +\beta_{2} I_{(\text {Aa } 1, A a 3)}+\beta_{3} I_{(A 1, A 3)}+\beta_{4} I_{(\text {Baa } 1, B a a 3)}+\beta_{5} I_{(B a 1, B a 3)}+\beta_{6} I_{(B 1, C a a)} \\
(1) & +\beta_{7}(M A T)+\beta_{8}(A M T)+\beta_{9} \text { PREM } \\
& +\beta_{10} C A L L+\beta_{11} S U B+\beta_{12} \operatorname{SINK} \\
& +\beta_{13} F X+\beta_{14} U T L
\end{aligned}
$$

The Control variables are defined as follows:

YLDSPD: The yield spread is calculated as the difference between the at-issue yield for the Yankee debt offer and the yield of a Treasury bond with similar maturity

$\boldsymbol{I}_{(\mathbf{A a a})}$ : Indicator variable denoting the Moody's rating of the issue. Equal to 1 if rated Aaa. Suppressed in the intercept term.

\footnotetext{
${ }^{5}$ Similar results are obtained when the total yield is used as the dependent variable.
} 


\section{William Davidson Institute Working Paper 445}

$I_{(\mathrm{Aa1}, \mathrm{Aa})}, \boldsymbol{I}_{(\mathrm{A} 1, \mathrm{~A} 3)}, \boldsymbol{I}_{(\mathrm{Baa} 1, \mathrm{Baa})}, \boldsymbol{I}_{(\mathrm{Ba1}, \mathrm{Ba3})}, \boldsymbol{I}_{(\mathrm{B} 1, \mathrm{Caa})}$ : Indicator variable denoting the Moody's rating of the issue. For example, $\boldsymbol{I}_{(\mathbf{A a} 1, \mathbf{A a} 3)}$ is Equal to 1 if rated Aa1, Aa2, or Aa3; 0 otherwise, $\boldsymbol{I}_{(\mathbf{A 1}, \mathbf{A} \mathbf{3})}$ is equal to 1 if rated $\mathrm{A} 1, \mathrm{~A} 2$ or $\mathrm{A} 3 ; 0$ otherwise, and so on.

MAT:The natural logarithm of the issue's maturity in years.

AMT:The natural logarithm of the dollar size of the net proceeds of the bond issue in $\$$ millions.

PREM: The difference between the Moody's Aaa seasoned corporate bond yield index and the composite Treasury yield on the offer date.

CALL: Indicator variable denoting the presence of a call provision: CALL equals 1 if the issue is callable; 0 otherwise.

SUB: Indicator variable denoting the presence of subordinated status. SUBORDINATED equals 1 if the issue is subordinated; 0 otherwise.

SINK: Indicator variable denoting the presence of a sinking fund feature. SINKINGFUND equals 1 if the issue contains a sinking fund provision; 0 otherwise.

FX: The 30-day historical volatility of the U.S. to home country currency exchange rate

UTL: Indicator variable denoting the firm is in the utility industry; UTIL equals 1 if issue is from a utility company; 0 otherwise.

The control variables account for differences in credit rating, maturity of issue, size of the issue, market risk premium, whether the issue has a call provision, whether the issue is subordinated, and whether the issue has a sinking fund feature. Because these variables have been used in previous studies, we provide only a limited discussion. We expect to find that the yield spread is negatively related to the bond's rating. We included the maturity of the issue to control for any term structure effects in the default premium. The size of the issue may be important if larger offerings have more public information than smaller issues, and therefore have less uncertainty. Also, large offerings may enhance future liquidity and hence may have lower yields. The variable PREM is defined as the yield spread between the Moody's Aaa seasoned corporate bond yield index and the composite Treasury yield index and is included to 


\section{William Davidson Institute Working Paper 445}

control for general economic conditions at the time of the sale. ${ }^{6}$ From the bondholder's perspective, bonds that are callable have prepayment risk. Therefore, we expect that callable bonds will have higher yield spreads. Similarly, subordinated bonds are riskier than senior debt, so the yield spread of subordinated debt should be higher than that of senior debt. The sign of the impact of a sinking fund is ambiguous: the presence of sinking funds can reduce the default risk of an issue by requiring orderly payment of the principal over the life of the bond, however, sinking funds are likely to be attached to riskier bonds (see Myers, 1977; Smith and Warner, 1979). Since exchange rate movements may affect investors' belief about the firms ability to cover interest payments, the historical volatility of the U.S. to foreign exchange rate may be positively related to the yield spread (Marr, Rogowski, and Trimble, 1989). If utility firms are perceived as lower risk, then investors may require lower spreads on these firms. In addition, other control variables were investigated. We examined additional ratings classifications, one using a simple dummy variable for investment grade debt, another assigning increasing numerical values to each rating class, and finally using individual dummies for each rating class. Regressions were performed using the historical mean return of the U.S. to home country currency exchange rate, and the historical volatility of U.S. Treasury rates. In all specifications, the results for the test variables discussed next remain robust

While specifications similar to ours have been used extensively in the literature, it is important to note that our model has several potentially undesirable features. One is the use of final maturity as a measure of the bond's payment schedule. Given various coupon payments and maturities, duration may better capture the relevant differences in payment schedules. Another is that the pricing equation allows for fixed increases in the yield-spread if a bond is callable, subordinated, or has a sinking fund provision. In theory, none of these features have fixed-effects on bond yields. Finally, the choice of issuing a Yankee bond may be endogenous in equilibrium. Ignoring this choice could result in a misestimated model due to selection bias. To address the first issue, we use the bond's duration instead of the final maturity and find our conclusions are unchanged. Next, we remove all bonds that are callable, subordinated, or have a

\footnotetext{
${ }^{6}$ We also used the BBB index and found similar results.
} 


\section{William Davidson Institute Working Paper 445}

sinking fund provision. Again, our results are robust to this specification. Finally, we address the issue of self-selection by correcting for potential selection bias. We employ Heckman's (1979) correction procedure to control for self-selection bias induced by the firm's decision to issue in the U.S. Here, the decision to issue in the U.S. market versus the Euro market is modeled based on purely exogenous factors such as firm and market characteristics. In results not reported here, we find our test variables remain correctly signed and significant. Given the finding that our results are robust with respect to the abovementioned limitations, we now turn to the model's estimation.

\subsection{Investor Protection Test Variables}

In general, when creditor rights are protected, investors are willing to pay more for securities (LLSV, 1999). Protection includes not only the rights written into laws and regulations, but the effectiveness of their enforcement. U.S. investors buying foreign public debt are likely to face a high degree of uncertainty regarding their legal protection. Therefore, we expect that investors would demand premiums on bonds issued by firms located in countries that do not protect investors' rights. One way we test this hypothesis is to examine firms domiciled in emerging markets. If the firm is domiciled in an emerging rather than developed market, we expect investors would face a higher degree of uncertainty and price bonds accordingly. This proxy is, however, a "catch all" for the various problems investors may face with regarding bondholder-shareholder conflicts. Therefore, we also examine variables from LLSV (1998) that rank countries' protection of investors' rights. These proxies are motivated by the studies that link capital market development and country specific legal institutions (see, e.g., LLSV, 1997, 1999). The first, creditor rights (CR), is an index aggregating different creditor rights a particular country provides. The index ranges from 0 to 4 , with 4 representing the highest protection. One point is added if there is no automatic stay on assets, secured creditors get paid first, there are restrictions on reorganizations, and if management does not stay in reorganizations. At the bottom of the scale are countries such as Mexico, Peru, and France. At the top of the scale are countries such as Hong Kong, United Kingdom, and Singapore. The second, rule of law (ROL), is in index of the law and order tradition of the country. It is 


\section{William Davidson Institute Working Paper 445}

scaled from 0 to 10 , with higher scores for counties with more tradition for law and order. Countries with the best rule of law include Canada, United States, and the Netherlands, while countries with the poorest include India, Indonesia, and the Philippines. These indices allow an examination into both aspects of creditor protections, rights written into laws (CR) as well as the effectiveness of their enforcement (ROL). We do not include a measure for local accounting standards given firms issuing Yankee bonds must adhere to U.S. reporting standards. The remaining LLSV (1998) variables, such as the risk of government expropriation and corruption, would seem less applicable in our analysis. However, as a robustness check, we replace our rule of law variable with the Berkowtiz, Pistor, and Richards (1999) legality index. Their Legality index is formed from a principal components analysis of the covariance matrix of the five LLSV legality variables: Efficiency of the Judiciary, Rule of Law, Corruption, Risk of Expropriation, and Risk of Contract Repudiation. Our results are robust with respect to this specification, and therefore we report specifications using the original rule of law variable.

\subsection{Firm-specific test variables}

If there is considerable uncertainty regarding the protection of bondholder rights, investors may require premiums for this uncertainty. In this environment, firms may benefit from actions that assure creditors in the United States.

Coffee (1999), La Porta (1999), and Stulz (1999) suggest one way foreign firms can certify they will act in the interest of U.S. investors is by cross-listing equity in the United States. LLSV (1999) define this opt-in mechanism of listing shares in the U.S. as an example of the "functional convergence" of legal systems that improve investor protection. ${ }^{7}$ While Yankee bonds must adhere to U.S. reporting requirements, a prior equity cross-listing would imply a history of on-going disclosure prior to the bond issue. In a study of U.S. high-yield bonds, Fenn (2000) provides evidence that this on-going disclosure is more important than the disclosure associated with the initial securities registration. In addition, cross-

\footnotetext{
${ }^{7}$ Important to note that only foreign stock listings on the NYSE, AMEX, or Nasdaq are associated with the high reporting and disclosure requirements. Non-U.S. firms listing over-the-counter or through the 144a market are exempt from the registration requirements of the Securities Act of 1933.
} 


\section{William Davidson Institute Working Paper 445}

listing equity increases analyst coverage and visibility of the firm, which may also increase information availability (Baker, Nofsinger, and Weaver, 1999). Therefore, the equity cross-listing mechanism can provide Yankee bond investors with valuable firm-specific information.

A second way foreign firms can certify they will act in the interest of U.S. investors is suggested by Diamond (1989). He argues that when there is a high degree of uncertainty in resolving bondholdershareholder conflicts, firms can benefit from developing a good reputation for repaying creditors. Therefore, foreign firms can assure U.S. investors by issuing debt in the U.S. In this view, borrowers deliver on their contracts not because they are forced to, but because doing so builds a good reputation that facilitates future access to capital markets at favorable terms. Another benefit to issuing debt is that once a firm has issued debt in the U.S. market, it is likely to provide credit analysts with relevant information on an on-going basis (Fenn, 2000).

Therefore, if a good reputation and better information availability are important, investors will, ceteris paribus, pay more for the Yankee bonds of firms that had previously issued debt in the U.S. market or cross-listed equity on U.S. markets prior to the Yankee bond offering. ${ }^{8}$ We test this by examining if investors require premiums for first-time issuers. The test variable, prior us offering (PRUS), is a dummy variable that indicates the presence of a previous US public debt or equity listing.

\footnotetext{
${ }^{8}$ The importance of these two mechanisms to non-U.S. firms is also evident in the financial press. One example from Euromoney (June 1993) entitled "Why it's important to get your Yankee issue right" discusses the implications of establishing firm's reputation of past borrowing in the U.S.:

“...US investors are unfamiliar with many foreign names, and so they have little sense for what rate new borrowers should pay. This offers an opportunity to issuers but also a danger: do the first deal right, and you will establish credibility and a reasonably low spread for future issues (emphasis added). Do the first deal wrong, and there may not be a second."
}

The October $21^{\text {st }}, 1991$ Investment Dealer's Digest provides an example of the benefits of a prior stock presence in the U.S. prior to the Yankee bond issue:

"On the heels of a highly successful stock offering four months ago, Societe Nationale Elf Aquitaine last week tapped the Yankee bond market with another hot deal. The $\$ 300$ million 10-year debt issue was the French firm's first in the U.S." “ ... The enhanced visibility afforded by the stock sale made the debt offering much easier, according to CFO Philippe Hustache. "It's good to be in the US dollar market," he added." 


\section{William Davidson Institute Working Paper 445}

\subsection{Results}

Model 1 of Table III shows that controlling for the underlying issue characteristics, the cost of debt is increased by 26 basis points ( $\mathrm{p}$-value $=0.06$ ) if the firm is located in an emerging market. Model 2 of Table III examines the effects of the investor protection and information variables on bond yields. We expect to find that bonds issued by firms located in countries that provide both strong laws protecting creditor rights and effective enforcement of these laws would be valued highest by investors. Consistent with this hypothesis, we find the coefficients on ROL and CR*ROL are negative and significant $(-0.064$, p-value $=0.01$ and -0.0109, p-value $=0.01$, respectively). ${ }^{9}$ We submit this as evidence consistent with LLSV (1999) who argue that investor protection laws matter most when they are accompanied by effective enforcement mechanisms. For example, moving from a country like Mexico that has relatively weak creditor protections and legal systems (creditor rights $=0$, rule of law $=5.35$ ) to a country like the United Kingdom that has relatively strong laws and enforcement (creditor rights $=4$, rule of law $=8.57$ )

decreases the annual yield spread of public corporate bonds by 58 basis points. ${ }^{10}$ It also is important to note that our tests are potentially biased against finding significant results, since issuing Yankee bonds require firms to adhere to U.S. reporting standards and give investors the right to sue in U.S. courts. If this has a greater effect on firms located in countries with poor investor protections, our results actually underestimate the costs these countries impose on their firms.

Model 2 of Table III also shows that the coefficient on prior us offering (PRUS) is negative and significant $(-0.41, \mathrm{p}$-value $=0.00)$. This indicates that after controlling for the baseline regression and country-level creditor protections, first-time issuers pay a 41 basis point premium. Therefore, investors require premiums both when their rights are not well protected as well as when they lack critical information regarding issuers. These results are even more striking when viewed in light of the sample composition. The sample firms are predominately developed-market firms issuing high-quality bonds. They would appear to be the least likely to suffer the "neglect" Merton (1987) discusses, yet the market 


\section{William Davidson Institute Working Paper 445}

still requires economically significant premiums for the first-time issuers. This would suggest that there is a significant information gap between U.S. investors and first-time foreign issuers, irrespective of the issuer's quality.

If information problems are driving the premium investors charge for first-time issuers, we would expect the premium to be largest in the most information-sensitive securities. Because noninvestment grade issues generally require more analysis and information than do investment grade, the benefit to a prior U.S. listing or issuance should be higher for noninvestment grade securities. Model 3 of Table III shows that for noninvestment grade issues $(\mathrm{J})$, the coefficient on PRUS*J is negative and significant (0.51, p-value $=0.07$. . Model 3 also shows that the coefficient for investment grade issues is again negative and significant, but lower in magnitude $(-0.22$, p-value $=0.03)$. The results are consistent with the hypothesis that investors demand higher premiums for uncertainty in the most information-sensitive securities.

What explains the premium investors require for first-time issuers? To examine this issue, we divide the test variable prior us offering (PRUS) into its two components, previous public-equity issue or cross-listing (PRST) and previous Yankee issue (PRYA). Model 4 of Table III shows that the coefficient on PRYA is also negative and significant $(-0.23, p$-value $=0.02)$. Therefore, a prior public debt offering increases the price investors are willing to pay for a firm's bonds. This is consistent with Diamond's (1989) hypothesis that a prior borrowing history can serve to build reputation that facilitates future access to capital markets at favorable terms. The finding is also consistent with Fenn (2000) who find a first-time issuer premium in the US high-yield bond market. He argues that in addition to reputation effects, the premium may result from importance of on-going information disclosure that is useful to credit agencies and investors. We also find support of this hypothesis in that the coefficient on PRST is negative and significant $(-0.35, p$-value $=0.00)$. Therefore, our results suggest that on-going information provided by an equity listing is also valued by investors. Overall, the effects appears to be similar for both groups, as

\footnotetext{
${ }^{9}$ We use RULE OF LAW as the base case since CREDITOR RIGHTS and the interaction term (CREDITOR
} 


\section{William Davidson Institute Working Paper 445}

we cannot reject the hypothesis that the coefficients are equal ( $p$-value of difference $=0.40$ ). This suggests that it is not just a borrowing reputation that provides investors with valuable information necessary to evaluate bond issues, but also on-going information disclosure. As further evidence of this finding, we report in Model 5 the effect of a previous 144a debt offering (PR144). ${ }^{11}$ The coefficient on PR144 is insignificant $(0.14, \mathrm{p}$-value $=0.57)$. Since bonds privately placed in the $144 \mathrm{a}$ market do not have to meet stringent U.S. reporting standards, the results further demonstrate the importance of disclosure in the pricing of Yankee bonds.

\subsubsection{Comparison to U.S. findings and Robustness checks}

To verify the robustness of these results, we performed several checks. Model 6 of Table III excludes the Canadian firms from the sample. We find that the coefficients on the CR*ROL and PRUS are correctly signed and significant. Therefore, the Canadian portion of the sample does not drive the

results. ${ }^{12}$ While the baseline regression suggested that industry effects are small, we re-estimated the model using industry dummies based on two-digit SIC codes: Manufacturing, Transportation, Communications, Utilities, Trade, Services, and Mining, Construction \& Agriculture. In regressions not reported here, we find the test variables remain correctly signed and significant. Finally, we included year dummies to control for time effects. Again, our results remain robust to this specification. Overall, the results provide support for the literature that suggests better legal protections and more detailed information disclosure increase the price investors will pay for financial assets.

To compare our Yankee bond finding with those reported in the U.S., we pooled data from Yankee and U.S. high-yield issues over the 1987-1998 time period. In regressions not reported here, we find the coefficient of a prior debt issue is -0.52 for the Yankee sample versus

-0.17 for the U.S. sample ( $p$-value of the difference $=0.06$ ). Hence, the premium for first-time issuers is larger for foreign firms than for U.S. firms, certeris paribus. The U.S. results confirm the work of Fenn

RIGHTS * RULE OF LAW) is highly correlated $(0.95)$.

${ }_{10}\{(-0.0643 * 5.35+-0.0109 * 5.35 * 0)-(-0.0643 * 8.57+-0.0109 * 8.57 * 4)\}=-0.581$

${ }^{11}$ Twenty-seven firms had a prior 144a debt offering. 
(2000) using our 1987-1998 time period. In addition, if our model is well specified, this finding suggests that investor uncertainty is potentially larger for foreign issues than for domestic bond issues.

\section{The stock price reaction to a Yankee bond offering}

In this section, we measure the stock price reaction to the announcement of a Yankee bond offering. Our event-study provides new evidence on the wealth effects of these international capitalraising instruments.

The sample consists of 90 fixed-rate U.S. dollar-denominated bonds issued in the U.S. by foreign firms over the period 1988 to 1998 . The sample is compiled from data from the SDC database. An issue must have had an identifiable announcement to be included in the sample. In addition, data on the underlying stock in the home country are required starting 125 days before the announcement date. ${ }^{13}$ Return data for each stock as well as the corresponding national market index are compiled from the Datastream International database. We follow Miller (1999) and collect announcement dates from the Lexis/Nexis database. Table IV offers information about the home country of the Yankee issuer, year in which the issue was made, maturity of the issue, size of the issue, and rating of the issue. As with our yield-analysis sample, a majority of this sample is comprised of firms from Canada, and the issues tend to occur in the later part of the sample period.

\subsection{Estimates of the stock price reaction}

To measure abnormal returns, we estimate a market model for each firm using local currency daily returns converted to U.S. dollar returns using daily exchange rates. Similar results are found using local currency returns. As a proxy for the market return, we use a market capitalization-weighted index

\footnotetext{
${ }^{12}$ If the CREDITIOR RIGHTS AND RULE OF LAW are used linearly (as in Model 3, Table III), the coefficients are -0.1042 (p-value $=0.03)$ and $-0.0810(\mathrm{p}$-value $=0.17)$ respectively.

${ }^{13}$ Lack of announcement dates and return data reduced the sample from 260 to 90 firms.
} 


\section{William Davidson Institute Working Paper 445}

for each country from Datastream. ${ }^{14}$ Abnormal returns are then averaged across firms to form the average abnormal return. Tests of significance are conducted using standardized abnormal returns (Brown and Warner, 1985).

Panel A of Table $\mathrm{V}$ presents average abnormal returns surrounding the announcement of a Yankee bond offering. Foreign firms announcing a public bond offering in the U.S experience positive and significant abnormal returns. For day -1 to +1 , the average abnormal return is $0.80 \%$ ( $p$-value $=$ 0.01). This results stand in sharp contrast to the results for public debt offerings by U.S. firms in the United States. For example, Eckbo (1986) finds that on average straight debt offerings by U.S. firms have non-positive price effects.

Our results, however, are consistent with Kim and Stulz (1988) who find a positive market reaction to Eurobond offerings issued by U.S. firms. In addition, Kang, Kim, Park and Stulz (1995) report positive and significant abnormal returns to offshore warrant bond issues of Japanese firms. This result contrasts the significant negative stock price reaction for U.S. equity-linked issues. In a study of U.S. firms raising capital abroad, Chaplinsky and Ramchand (1999) find the stock price reaction is less negative for these offshore issues than for comparable domestic issues. Further, Gande (1996) and Miller (1999) report positive announcement returns for public equity issues of Depositary Receipts (DRs). Because their samples include capital-raising initial dual listings, they are a joint test of the stock price effects of equity issuance as well as international market segmentation. Nonetheless, they find a positive stock price reaction to public equity offerings in the U.S. by foreign firms. Therefore, our positive stock price reaction to a Yankee bond offering appears to be consistent with recent research on securities issues outside a firm's domestic market. Overall, our results suggest that issuing Yankee bonds is associated with an increase in shareholder value.

We next examine potential explanations for the positive stock price reaction to the announcement of a Yankee bond issue. Stulz (1999), Cantale (1998), and Fuerst (1998) argue that issuing securities in a

\footnotetext{
${ }^{14}$ To verify the robustness of the results, various methodologies are employed to calculate abnormal returns. The
} 


\section{William Davidson Institute Working Paper 445}

high disclosure environment is a signal of firm quality. They reason that issuing public securities in the U.S. is costly, both in terms of higher disclosure levels as well as fixed costs. Therefore, only quality firms would find it beneficial to do so. Yankee bond issues also require SEC disclosure and entail the substantial fixed-costs of a public bond issue. Hence, Yankee bond issuance can also be viewed as a signal of quality. Merton's (1987) model of investor recognition would also predict an increase in shareholder wealth for a Yankee bond offering, since issuing in the US Yankee bond market is likely to increase the visibility of a firm and thus broaden the firm's investor base.

To further examine the signaling hypothesis and investor recognition hypothesis, we distinguish between first-time issues and repeat issues. We define a first-time issuer as a firm that had not previously issued or listed public debt or equity in the U.S. The signaling hypothesis predicts that the positive impact of the first issue will be larger than that of subsequent issues. The investor recognition hypothesis also predicts that the incremental effect on investor recognition will be largest for first-time issues. Finally, Kim and Stulz (1988) argue that if reputation is indeed important to investors and results in lower subsequent borrowing costs, shareholder wealth would increase the most on the announcement of the first bond offering. Hence, we expect that first-time issues would have a larger stock price reaction.

Panel B of Table V reports the average abnormal returns for the sample with and without a prior U.S. offering. The abnormal returns of both PREVIOUS ISSUE and FIRST-TIME ISSUE are positive and significant $(0.56 \%, p$-value $=0.04$ and $1.52 \%, p$-value $=0.05$, respectively $)$. As predicted, we find the stock price reaction is largest for firms that have not previously issued public debt or cross-listed equity in the Unites States $(p$-value of the difference $=0.04$ ). Table V also reports additional univariate breakdowns

for robustness checks. ${ }^{15}$ Panel $\mathrm{C}$ shows that firms located in emerging markets have larger stock price reactions than do those from developed markets. While this result would also appear consistent with the signaling hypothesis and investor recognition hypothesis, the sample from emerging market is small and

results are robust to changes such as currency denomination (e.g., local or U.S. dollars) and market index (e.g., local or Datastream World Market index). 


\section{William Davidson Institute Working Paper 445}

the difference is not statistically significant. Also, Panel $\mathrm{C}$ reports that the stock price reaction is positive and significant for both the Canadian as well as non-Canadian portion of our sample, indicating that the results are not driven by the Canadian portion of the sample. The multi-jurisdictional disclosure system of 1991 allows Canadian companies to meet SEC reporting requirements with Canadian disclosure documents. Also, due to the geographical proximity and high integration of the Canadian and U.S. economies, one would expect higher investor recognition of Canadian firms relative to other foreign issuers. Hence, a smaller stock price reaction for the Canadian sample is predicted by both the signaling and investor recognition hypotheses. While the direction of the stock price reactions is consistent with these hypotheses, the difference is not significant.

\section{The determinants of market choice}

In this section, we develop a framework to analyze the factors that determine whether a firm issues a Yankee bond, paying special attention to the relative interest costs in the Yankee market. Kim and Stulz (1988) propose that firms may be able to exploit temporary financing opportunities and issue bonds in the market where interest costs are lowest. Our results provide new insights into why foreign firms choose a particular market to raise debt capital and how relative interest costs drive the decision.

\footnotetext{
${ }^{15} \mathrm{We}$ also performed additional cross-sectional analyses of the stock price reaction. Consistent with the findings of Eckbo (1986), these cross-sectional regressions did not reveal any relation between the stock price reaction and issue characteristics such as offering size and rating.
} 


\section{William Davidson Institute Working Paper 445}

\subsection{The firm's choice}

In our model, a firm chooses between issuing a bond in the Yankee market or in the Euro market. Firms issuing Eurodollar bonds circumvent many of the U.S. securities laws. For example, Eurodollar bonds do not have to adhere to SEC regulations, and therefore avoid the stringent U.S. reporting requirements. In addition, Eurodollar bonds are issued in unregistered, or bearer, form. This allows confidentially of ownership, which might be important to investors for many reasons, not the least of which is the ability to avoid taxes. Since Eurodollar issues do not adhere to U.S securities laws, they cannot be sold to U.S. investors. To prevent U.S. investors from buying newly issued Eurobonds, the SEC requires a "seasoning" period in which sales of Eurobonds to U.S. investors can take place only 90 days after the issue date. ${ }^{16}$

The investor base for Eurodollar bonds also distinguishes the Eurodollar market from the Yankee bond market. Where institutional investors with long-term investment horizons tend to dominate the U.S. corporate bond market, private investors have played a significant role in the demand for Eurobonds. In general, private investors have been perceived to prefer shorter-term bonds. As the Euro market becomes more institutionalized, central banks and insurance companies have become the major investors. However, these institutions also prefer short-term maturities because of liquidity needs and foreign exchange risk. As a result, most Eurobonds tend to have maturities of 3 to 10 years. Whereas Yankee bonds pay coupons semi-annually, Eurodollar bonds pay interest annually.

\subsection{Econometric framework}

In our model, we assume that if firms decide against issuing a Yankee bond (which would be dollar dominated and rated), they would issue a rated Eurodollar bond. While we argue that this is the most probable scenario, an obvious disadvantage of this specification is that it does not allow for all possible firm choices. For example, the choice may be between a Yankee bond or a rated EuroYen bond,

\footnotetext{
${ }^{16}$ To comply with the SEC requirement, Eurobond underwriters initially distribute registered shares of the offering. After a 90 day seasoning period, they offer the option to convert these shares to individual bearer bonds. While U.S.
} 


\section{William Davidson Institute Working Paper 445}

between a Yankee bond or a non-rated EuroPeso bond. By comparing Yankee issues to a sample of rated Eurodollar bonds, we gain two advantages. First, abstracting from the choice of which currency to issue in should enable us to focus better on the choice between regulatory environments. Using bonds denominated in different currencies would necessitate controlling for the choice of currency in addition to the choice of market. For example, Kedia and Mozumdar (1999) find that the use of foreign currency denominated debt is related to various factors including the aggregate foreign exchange exposure of the firm, liquidity of the debt market, protection of creditor rights, and information asymmetries. Allayannis and Ofek (1998) also show hedging considerations motivate the use of foreign currency debt. Second, since ratings are such an important component of the bond pricing equation, analyzing rated bonds denominated in the same currency sample should allow for meaningful comparisons across markets. Bond ratings enable us to compute a Yankee/Euro cost differential that is (potentially) one of the most important factors firms consider when choosing a bond market.

The model we develop in this section is one of a class of models described by Maddala and Nelson (1975) as switching regression models with endogenous switching. ${ }^{17}$ The framework consists of two yield spread equations (one for Yankees, one for Eurodollar bonds) as well as an equation that describes the dichotomous market choice decision. One way to think of the framework is that the sample observations fall into two mutually exclusive regimes, with the decision equation serving as an endogenous selectivity criterion that determines the appropriate regime (Yankee versus Eurodollar). If firms choose a particular market because of some expected incremental benefit, then they may be nonrandomly distributed within the population. We take this selection bias into account during estimation.

The model consists of the following three equations,

$$
\begin{aligned}
& \log Y L D S P D_{Y i}=\theta_{Y o}+\theta_{Y 1} X_{Y i}+\theta_{Y 2} I_{Y i}+\varepsilon_{Y i} \\
& \log Y L D S P D_{E i}=\theta_{E o}+\theta_{E 1} X_{E i}+\theta_{E 2} I_{E i}+\varepsilon_{E i}
\end{aligned}
$$

investors can purchasing these bearer bonds in the secondary market after 90 days, liquidity in Eurobond secondary market is generally recognized to be low. 


$$
I_{i}^{*}=\delta_{0}+\delta_{1}\left(\log Y L D S P D_{E i}-\log Y L D S P D_{Y i}\right)+\delta_{2} X_{i}+\delta_{3} I_{i}+\delta_{4} M_{i}-\varepsilon_{i}
$$

where

$$
\varepsilon_{Y} \sim N\left(0, \sigma_{Y}^{2}\right), \varepsilon_{E} \sim N\left(0, \sigma_{E}^{2}\right), \text { and } \varepsilon \sim N\left(0, \sigma_{\varepsilon}^{2}\right)
$$

In this model, the net interest cost of the issue is determined by Eq. (2) if it is a Yankee bond, or by Eq.

(3) if it is a Eurodollar bond. $Y L D S P D_{Y i}, Y L D S P D_{E i}$ are the respective Yankee and Euro yieldspreads

for firm $i, X_{Y i}$ and $X_{E i}$ are the respective bond characteristics for Yankee and Eurobonds, while $I_{Y i}$ and $I_{E i}$ are the legal and information variables. The firm uses this information as part of its decision function (Eq. 4) in deciding which market to sell bonds in. However, we only observe the interest cost of the bond the firm selects to issue. That is, we observe $Y L D S P D_{Y i}$ if $I_{i}^{*}>0, Y L D S P D_{E i}$ otherwise, but never both. ${ }^{18}$ This introduces a selection bias that causes the OLS estimation of Eq. (2) and (3) to give inconsistent estimates. ${ }^{19}$ We estimate the model consistently using a Full Information Maximum Likelihood (FIML) estimator. For details of consistent estimators in the presence of selection bias, see Heckman (1976), and Lee (1978).

An advantage of our modeling approach is that we can estimate the structural form of the market location equation (Eq. 4). Using our estimates and Eq. (2) and (3), we calculate

$$
\begin{gathered}
\mu_{Y i}=\log Y L \hat{D} S P D_{Y i}=\hat{\theta}_{Y o}+\hat{\theta}_{Y 1} X_{Y i}+\hat{\theta}_{Y 2} I_{Y i} \\
\mu_{E i}=\log Y L \hat{D} S P D_{E i}=\hat{\theta}_{E o}+\hat{\theta}_{E 1} X_{E i}+\hat{\theta}_{E 2} I_{E i}
\end{gathered}
$$

\footnotetext{
${ }^{17}$ For a general discussion of models of this class, see Maddala (1983). For an application to unions and wages, see Lee (1978). For an application to private versus public bonds, see Kwan and Carleton (1998).

${ }^{18}$ Recently, simultaneous offerings in more than one market have begun to take place. Over our sample period, only 14 of these "Global" bond offerings were issued. Our findings are robust to their inclusion.

${ }^{19}$ The problems occurs because $E\left(\varepsilon_{Y} \mid I_{i}^{*}>0\right) \neq 0$ and $E\left(\varepsilon_{E} \mid I_{i}^{*} \leq 0\right) \neq 0$
} 


\section{William Davidson Institute Working Paper 445}

This framework allows us to obtain for each bond an estimate of the issue cost in the market the firm did not choose. This can be used to create the interest cost differential, which is an endogenous factor in the structural form equation. $^{20}$

\subsection{Data}

Our Eurodollar sample includes 128 issues from firms located in 14 countries. Important to note is that our Eurodollar bond sample differs in many respects from our Yankee bond sample (Table II). As expected, the Eurodollar bonds tend to be of shorter maturity, have higher credit ratings, and do not support call provisions. Therefore, these differences temper the "substitutability" of Yankee and Eurodollar issues. The differences in bond contract characteristics across the Yankee and Eurodollar markets have important implications for our methodology because we assume that firms can choose the types of bonds they issue in each market. For example, if long-maturity speculative-grade issues are simply not available in the Euro market, it may not be appropriate to estimate a perceived interest cost for those types of bonds in the Euro market. Therefore, we exclude Yankee issues with maturities greater than 10 years, issues that are non-investment grade, and those with call provisions. ${ }^{21}$ This leaves 98 Yankee issue that are comparable in issue characteristics to our Eurodollar sample.

\subsection{Discussion of the variables}

In estimating the interest cost equations (2) and (3), we use the same exogenous variables utilized in the previous OLS analysis. In addition to the endogenously determined Yankee-Euro yield spread $\left(Y L D S P D_{E}-Y L D S P D_{Y}\right)$, we utilize the following additional exogenous variables in estimating the criterion function (equation 4):

ACCT: index rating of a country's accounting standards, based on the inclusion or omission of 90 items in the firm's annual report. Taken from LLSV (1998).

\footnotetext{
${ }^{20}$ Lee (1979) shows these structural form probit estimates to be consistent.

${ }^{21}$ A previous version of the paper included all Yankee issues. After correcting for any potential selection bias, the coefficients on the previous test variables were correctly signed and significant. These results are available from the authors' upon request.
} 


\section{William Davidson Institute Working Paper 445}

YNK SPD: difference between the Lehman composite Yankee bond index and the Lehman composite Eurobond index

Therefore, when deciding where to issue bonds, the firm bases its decision on the characteristics of the contract (MAT, AMT) the effect of information disclosure (PRUS , ACCT), as well as the local legal environment (CR, ROL). The inclusion of issue characteristics allows us to measure how the contract design influences the choice of market. Our information variables proxy for the costs associated with meeting the stringent US reporting requirements. All else held equal, we expect that firms that already have meet U.S. requirements and/or disclose more would find it less costly to issue Yankee bonds. In addition, the difficulty of verifying cash flows in countries with poor accounting standards may reduce the menu of financial contracts available to firms and investors (LaPorta and Lopez-de-Silanes, 1998). The legal variables are included to determine if creditor protections influence the choice of market. Finally, we include the variable YNK SPD to allow for any potential influence of yield spreads between the Yankee and Euro market on the firm's decision. ${ }^{22}$

\subsection{Structural form probit estimates}

Using our consistent estimates of the two bond-pricing equations, we now estimate the interest cost differential between the Yankee and the Eurodollar market using Eq. (5) and (6). This can be used to create the interest-cost differential, which is an endogenous factor in the structural form of Eq. (4). If, as Kim and Stulz (1988) suggest, firms actively seek financing bargains, we should find that the interest-cost differential is a significant factor determining where firms issue bonds. Table VI reports these estimates.

We find that the coefficient of the estimated interest-cost differential is positive and significant (16.2533, $p$-value $=0.00)$. This result is consistent with the hypothesis that when interest costs of Eurodollar bonds are relatively higher than Yankee bonds, firms are more likely to issue in the Yankee

\footnotetext{
${ }^{22} \mathrm{We}$ also attempted to analyze firm level variables that have been shown to determine the length of debt that U.S. firms issue, including firm size and growth opportunities (See, for example, Barclay and Smith 1995; Guedes and Opler 1996). However, lack of accounting data for the majority of the sample precluded this analysis. In addition, the prevailing differences in accounting conventions across countries would make interpretation of the results problematic.
} 


\section{William Davidson Institute Working Paper 445}

market. Therefore, our findings are consistent with Kim and Stulz (1988) who argue that the relative interest cost in each market is a significant factor determining where firms choose to sell bonds. ${ }^{23}$

In addition, we find other factors that are significantly related to the choice of market. The coefficient on PRUS is also significantly positive $(0.9180, p$-value $=0.01)$. Firms are more likely to issue Yankee bonds if they have previously met U.S. reporting and disclosure requirements. For example, a firm with an ADR trading on the NYSE already conforms to SEC regulations, so the additional direct reporting costs would be negligible. Any potential loss of confidentiality after meeting SEC regulations would have been experienced previously by the firm, again making the Yankee issue relatively more attractive than to a firm that is only meeting its home country standards. We also find the coefficient on ACCT is positive and significant, indicating that firms located in countries with more transparent reporting standards are more likely to issue in the U.S. market. These results provide empirical support for the recent models of Chemmanur and Fulghieri (1999) and Huddart et al., (1999). In these models, the choice of exchange is related to the cost of complying with the exchange's disclosure requirements.

Table VI reports that coefficients on CR and ROL are both negative and significant $(-2.1253$, pvalue $=0.00$, and $-1.3598, p$-value $=0.00$, respectively). Consistent with Coffee (1999), Stulz (1999), and La Porta (1999), we find that that firms located in countries that have lower investor protections more often "opt-in" to the U.S.'s more investor-friendly legal system. Firms with better investor protections are less likely to benefit from the U.S. legal enforcement and will more likely, ceteris paribus, issue bonds in the unregulated Eurodollar market.

Finally, we do not find that the yield spread between the index of Yankee and Eurobond issues (YNK SPD) influences the firm's choice of market. While this may appear inconsistent with the clientele hypothesis of Kim and Stulz (1988), several points are worth noting. First, it is important to recall that each firm has a particular reservation interest-cost differential, which depends on additional non-interest cost factors. In addition, our findings show that firms do indeed use the perceived interest-cost differential

\footnotetext{
${ }^{23}$ On average, the estimated interest cost for Yankee bonds are 23\% less than comparable Eurobonds.
} 


\section{William Davidson Institute Working Paper 445}

(obtained from the switching regression model) in the market choice decision. The coefficient on YNK SPD merely indicates that after controlling for this interest cost differential, the market yield spread has no marginal explanatory power a firm's market choice. Second, the index of Yankee and Eurobond issues contain bonds of different maturities (the average Yankee bond is of longer maturity than the average Eurobond), so YNK SPD may reflect term structure effects rather than relative borrowing costs. ${ }^{24}$

\section{Conclusion}

Our analysis of a sample of Yankee bond issues provides support for the literature that suggests better legal protections and more detail information disclosure increases the price investors will pay for financial assets. We find that investors require economically significant premiums for bonds issued by firms located in countries with poor investor protections. For example, moving from a country like Mexico that has relatively weak creditor protections and legal systems to a country like the United Kingdom that has relatively strong laws and enforcement decreases the annual yield spread of public corporate bonds by 58 basis points, ceteris paribus. Our results also show that investors demand premiums on the bonds of first-time issuers. This is, public borrowing costs were 41 basis points lower if the foreign firm had listed or issued public securities in the U.S. prior to the debt offering. This reduction in public borrowing costs is found for both prior public debt issues (Yankee bonds) and prior stock crosslistings (ADRs or direct listings) and is largest in non-investment grade securities.

We also provide new evidence on the stock price reaction to public debt offerings in the U.S. made by overseas firms. Our results show that the stock price reaction to announcement of a Yankee bond offering is positive and statistically significant, providing evidence that firms benefit from raising public debt in the United States. We also find that the stock price reaction is largest for first-time issuers,

\footnotetext{
${ }^{24}$ One possible alternative spread is formed by World Bank global bonds that trade in each market (of the same maturity). However, contemporaneous data in each market were unavailable for these bonds.
} 


\section{William Davidson Institute Working Paper 445}

consistent with the hypotheses that issuing Yankee bonds in the U.S. signals quality, widens the firm's investor base, or both.

Finally, our analysis provides new insights into why foreign firms choose a particular market to raise debt capital and how relative interest costs drive the decision. We model the joint determination of market choice and interest costs using a switching regression model with endogenous switching. We find that one of the main factors that influences where a firm sells bonds is the relative interest costs between markets. Firms tend to issue in the Yankee market when the relative interest cost in the Eurodollar market is high, indicating potential differences in borrowing costs influence where firms choose to sell bonds. 


\section{William Davidson Institute Working Paper 445}

\section{References}

Allayannis, George and Eli Ofek, 1998, Exchange rate exposure, hedging and the use of foreign currency derivatives, Journal of International Money and Finance, forthcoming.

Baker, Kent, John R. Nofsinger and Daniel G. Weaver, 1999, International cross-listing and visibility, unpublished working paper, The New York Stock Exchange.

Barclay, Michael J. and Clifford W. Smith, Jr., 1995, The maturity structure of corporate debt, Journal of Finance 50, 609-631.

Blackwell, D. and D. Kidwell, 1988, An investigation of cost differences between public sales and private placements of debt, Journal of Financial Economics 22, 253-278.

Berkowitz, D., K. Pistor, and J.F. Richard, 1999, Economic development, legality, and the transplant effect, University of Pittsburgh working paper, November.

Brown, S., and Warner, J., 1985, Using daily stock returns: The case of event studies, Journal of Financial Economics 14, 3-31.

Cantale, Salvatore, 1998, The choice of a foreign market as a signal, Unpublished working paper, Tulane University.

Chaplinsky, Susan, and Latha Ramachandran, 1999, The impact of global equity offerings, The Journal of Finance, forthcoming.

Chaplinsky, Susan, and Latha Ramachandran, 2000, The Impact of SEC Rule 144A on Corporate Debt Issuance by Foreign Firms, unpublished working paper, University of Virginia.

Chemmanur, Thomas J. and Paolo Fulghieri, 1999, Choosing an exchange to list equity: A theory of cross-listing, listing requirements, and competition among exchanges, Unpublished working paper, Boston College.

Coffee, J., 1999, The future as history: The prospects for global convergence in corporate governance and its implications, Northwestern University Law Review, 641-708.

Diamond, Douglas W., 1989, Reputation acquisition in debt markets, Journal of Political Economy 97, 828-862.

Eckbo, B. Espen, 1986, Valuation effects of corporate debt offerings, Journal of Financial Economics, vol. 119-151.

Ederington, L., 1975, Uncertainty, competition, and costs in corporate bond underwriting, Journal of Financial Economics 2, 71-94.

Errunza, Vihang and Darius Miller, 1999, Valuation Effects of Global Equity Offerings: Evidence from Depositary Receipts, unpublished working paper, Texas A\&M University 


\section{William Davidson Institute Working Paper 445}

Fabozzi, Frank J., 1997, The handbook of fixed income securities, $5^{\text {th }}$ edition.

Fenn, George W., 2000, Speed of Issuance and the adequacy of disclosure in the 144A high-yield debt market, Journal of Financial Economics 56, 383-405.

Finnerty, J., 1985, Zero coupon bond arbitrage: An illustration of the regulation dialectic at work, Financial Management, Winter, 13-18.

Finnerty, J. and K.P. Nunn, 1985, The determinants of yield spreads on U.S. and Eurobonds, Management International Review, $2^{\text {nd }}$ quarter, 23-33.

Finnerty, Joseph E., Thomas Schneeweis, and Shantaram P. Hegde, 1980, Interest rates in the \$Eurobond market, Journal of Financial and Quantitative Analysis 15, 743-755.

Fuerst, O., 1998, A theoritical analysis of the investor protection regulations: Argument for global listing of stocks, unpublished working paper, Yale School of Management.

Giddy, Ian, 1994, Global Financial Markets, D.C. Heath and Company, Lexington, MA.

Guedes, Jose and Tim Opler, 1996, The determinants of the maturity or corporate debt issues, Journal of Finance 51, 1809-1833.

Heckman, J., 1976, The common structure of statistical models of truncation, sample selection, and limited dependent variables and a simple estimator of such models, Annals of Economics and Social Measurement 5, 475-492.

Heckman, J., 1979, Sample selection bias as a specification error, Econometrica 47, 153-161.

Huddart, Steven, John S. Hughes, and Markus Brunnermeier, 1999, Disclosure requirements and stock exchange listing choice in an international context, Journal of Accounting and Economics, forthcoming.

Kang, J. K., Y. C. Kim, K. J. Park, and R. M. Stulz, 1995, An analysis of the wealth effects of Japanese offshore Dollar denominated convertible and warrant bond issues, Journal of Financial and Quantitative Analysis 30, 257-270.

Karolyi, G. A., 1998, Why do companies list their shares abroad? A survey of the evidence and its managerial implications, unpublished working paper, Richard Ivey School of Business.

Kedia, Simi and Abon Mozumdar, 1999, Is foreign currency denominated debt a hedging instrument?, Unpublished working paper, Virginia Tech.

Kidwell, David S., M. Wayne Marr, and G. Rodney Thompson, 1985, Eurodollar bonds: Alternative financing for U.S. companies, Financial Management, Winter, 18-27.

Kidwell, David S., M. Wayne Marr, and J.L. Trimble, 1987, Domestic versus Euromarket bond sale: A persistent borrowing cost advantage, Unpublished working paper.

Kim, Y.C. and R.M. Stulz, 1988, The Eurobond market and corporate financial policy: A test of the clientele hypothesis, Journal of Financial Economics 22, 189-205. 


\section{William Davidson Institute Working Paper 445}

Kwan, Simon H. and Willard T. Carleton, 1998, Financial Contracting and the choice between private placement and publicly offered bonds, Unpublished working paper.

La Porta, Rafael, Florencio Lopez-de-Silanes, and Andrei Shleifer, 1998, Law and finance, Journal of Political Economy 106, 1113-1155.

La Porta, Rafael, Florencio Lopez-de-Silanes, Andrei Shleifer, and Robert W. Vishny, 1997, Legal determinants of external finance, Journal of Finance 52, 1131-1150.

La Porta, Rafael and Florencio Lopez-de-Silanes, 1998, Capital markets and legal institutions, Working Paper, Harvard Unversity.

La Porta, Rafael, Florencio Lopez-de-Silanes, Andrei Shleifer, and Robert W. Vishny, 1999, Investor protection and corporate governance, Journal of Financial Economics, forthcoming.

Lee, Lung-Fei, 1978, Unionism and wage rates: A simultaneous equations model with qualitative and limited dependent variables, International Economic Review 19, 415-433.

Lee, Lung-Fei, 1979, Identification and estimation in binary choice models with limited (censored) dependent variables, Econometrica 47, 977-996.

Lombardo, D., and Marco Pagano, 2000, Legal Determinants of the Return on Equity, Unpublished Working Paper.

Maddala, G.S., 1983, Limited-dependent and qualitative variables in econometrics, Cambridge University Press, New York.

Maddala, G.S. and Forest D. Nelson, Switching regression models with exogenous and endogenous switching. Proceedings of the Business and Economic Statistics Section, American Statistical Association, 1975, 423-26.

Mahajan, Arvind, and Donald Fraser, 1986, Dollar Eurobond and U.S. bond pricing, Journal of International Business Studies, Summer, 21-36.

Marr, M. Wayne, Robert W. Rogowski, and John L. Trimble, 1989, The competitive effects of U.S. and Japanese commercial bank participation in Eurobond underwriting, Financial Management, Winter, 47-54.

Merton, Robert C., 1987, A simple model of capital market equilibrium with incomplete information, Journal of Finance 42, 483-510.

Miller, Darius P., 1999, The market reaction to international cross-listings: Evidence from depositary receipts, Journal of Financial Economics 51, 103-123.

Rajan, Raghuram, and Luigi Zingales, 1998, Financial dependence and growth, American Economic Review 88, 559-587.

Stulz, Rene M., 1999, Globalization of equity markets and the cost of capital, unpublished working paper, New York Stock Exchange. 


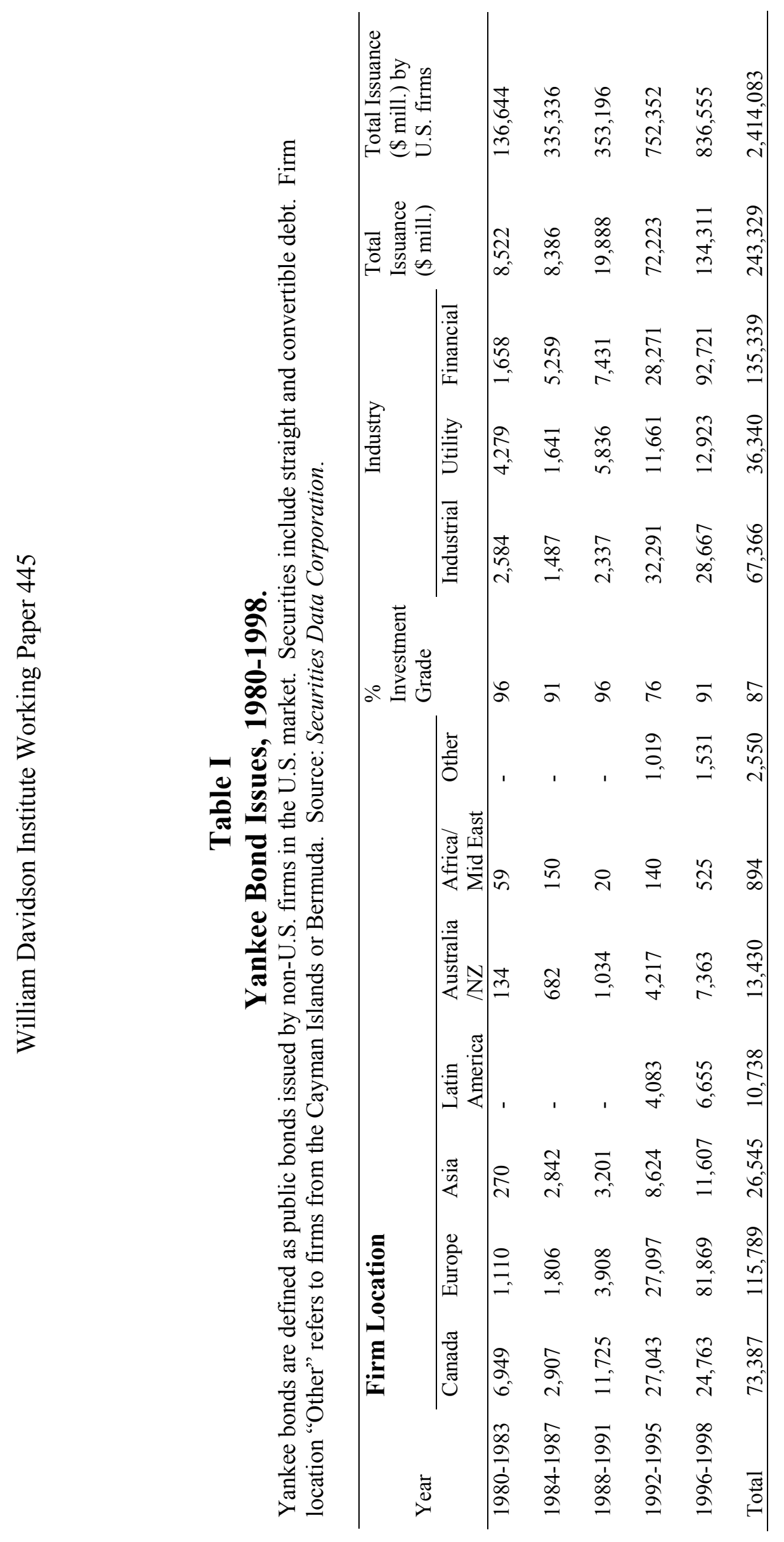




\section{Table II}

Frequency distribution of Yankee bonds made by non-U.S. firms, 1987-1998.

Yankee bonds are defined as public bonds issued by non-U.S. firms in the U.S. market. All issues are fixed-rate corporate bonds denominated in U.S. dollars.

\begin{tabular}{|c|c|c|}
\hline Panel A. Offering Year & & \\
\hline & Number & Percent \\
\hline 1987-1989 & 10 & 3.8 \\
\hline 1990-1992 & 43 & 16.6 \\
\hline 1993-1995 & 88 & 33.8 \\
\hline 1996-1998 & 119 & 45.8 \\
\hline Total & 260 & 100.0 \\
\hline \multicolumn{3}{|l|}{ Panel B. Firm location } \\
\hline Asia & 24 & 9.2 \\
\hline Canada & 151 & 58.1 \\
\hline Europe & 53 & 20.4 \\
\hline Latin America & 32 & 12.3 \\
\hline Total & 260 & 100.0 \\
\hline \multicolumn{3}{|l|}{ Panel C: Industry Distribution } \\
\hline Communications & 32 & 12.3 \\
\hline Manufacturing & 97 & 37.2 \\
\hline Mining, Construction & & \\
\hline Agriculture & 64 & 24.5 \\
\hline Utilities & 41 & 15.7 \\
\hline Transport, Trade and Services & 27 & 10.3 \\
\hline Total & 260 & 100.0 \\
\hline \multicolumn{3}{|l|}{ Panel D : Summary Statistics } \\
\hline Issue Size ( $\$$ millions) & 214.80 & \\
\hline Years to maturity & 14.51 & \\
\hline $\begin{array}{l}\% \text { of issues that are investment } \\
\text { grade }\end{array}$ & 74.62 & \\
\hline$\%$ of issues with Call provisions & 32.31 & \\
\hline$\%$ of issues with Sinking Fund & 1.92 & \\
\hline$\%$ of issues of Subordinated debt & 3.8 & \\
\hline $\begin{array}{l}\% \text { of issues with a prior U.S. } \\
\text { equity cross-listing }\end{array}$ & 59.2 & \\
\hline$\%$ of issues with a previous U.S. & & \\
\hline public debt offer & 48.1 & \\
\hline $\begin{array}{l}\% \text { of issues with a prior U.S. } \\
\text { offering }\end{array}$ & 74.6 & \\
\hline
\end{tabular}




\section{Table III \\ Multivariate tests of first-time issuer effects}

Regression estimates of yield spread on bond characteristics, market conditions and country variables. Yield spread is the offering yield-to-maturity (on the net proceeds of the offer, after total manager's fees) in excess of the yield on similar maturity treasuries. Emerging dummy is 1 for issues from emerging country firms. Aaa rated bonds are included in the intercept term CR is an index of different creditor rights and ranges from 0 to 4 with 4 indicating best creditor rights. ROL assesses law and order tradition of a country and ranges from 0 to 10 with 10 indicating best rule of law. PRUS is a dummy variable that indicates the presence of a previous U.S. public debt offer or a U.S. equity cross-listing. PRST is a dummy variable that indicates the issuer's stock was listed on a U.S. stock exchange at the time of the bond issue. PRYA is a dummy variable that indicates the presence of a previous U.S. public debt offer. Aaa rated bonds are included in the intercept term. P-values (in parentheses) are computed using heteroskedastic consistent variance estimates. * and ** indicate significance at the 0.1 and 0.05 levels, respectively.

\begin{tabular}{|c|c|c|c|c|c|c|}
\hline & $\begin{array}{c}\text { Model } 1 \\
\text { Full Sample }\end{array}$ & $\begin{array}{c}\text { Model } 2 \\
\text { Full Sample }\end{array}$ & $\begin{array}{c}\text { Model } 3 \\
\text { Full } \\
\text { Sample } \\
\end{array}$ & $\begin{array}{c}\text { Model } 4 \\
\text { Full Sample }\end{array}$ & $\begin{array}{c}\text { Model } 5 \\
\text { Full Sample }\end{array}$ & $\begin{array}{c}\text { Model } 6 \\
\text { Excluding } \\
\text { Canada }\end{array}$ \\
\hline INTERCEPT & $\begin{array}{l}1.9849 * * \\
(0.00)\end{array}$ & $\begin{array}{l}2.6903 * * \\
(0.00)\end{array}$ & $\begin{array}{l}2.8448 * * \\
(0.00)\end{array}$ & $\begin{array}{l}2.4284 * * \\
(0.00)\end{array}$ & $\begin{array}{l}2.2136 * * \\
(0.00)\end{array}$ & $\begin{array}{l}-0.3793 \\
(0.71)\end{array}$ \\
\hline EMERGING & $\begin{array}{l}0.2606 * \\
(0.06)\end{array}$ & & & & & \\
\hline ROL & & $\begin{array}{l}-0.0643 * * \\
(0.04)\end{array}$ & $\begin{array}{l}-0.0778 * * \\
(0.02)\end{array}$ & $\begin{array}{l}-0.0605 * \\
(0.06)\end{array}$ & $\begin{array}{l}-0.04946 \\
(0.22)\end{array}$ & $\begin{array}{l}-0.0777 \\
(0.14)\end{array}$ \\
\hline $\mathrm{CR} * \mathrm{ROL}$ & & $\begin{array}{l}-0.0109 * * \\
(0.01)\end{array}$ & $\begin{array}{l}-0.0109 * * \\
(0.01)\end{array}$ & $\begin{array}{l}-0.01275 * * \\
(0.00)\end{array}$ & $\begin{array}{l}-0.01209 * * \\
(0.00)\end{array}$ & $\begin{array}{l}-0.0096 * \\
(0.06)\end{array}$ \\
\hline PRUS & & $\begin{array}{l}-0.4072 * * \\
(0.00)\end{array}$ & $\begin{array}{l}-0.2216 * * \\
(0.03)\end{array}$ & - & - & $\begin{array}{l}-0.3923 * * \\
(0.00)\end{array}$ \\
\hline PRUS*J & & - & $\begin{array}{l}-0.5155 * \\
(0.07)\end{array}$ & - & - & - \\
\hline PRYA & & - & - & $\begin{array}{l}-0.2276 * * \\
(0.02)\end{array}$ & $\begin{array}{l}-0.2280 * * \\
(0.02)\end{array}$ & - \\
\hline PRST & & - & - & $\begin{array}{l}-0.3513 * * \\
(0.00)\end{array}$ & $\begin{array}{l}-0.3541 * * \\
(0.00)\end{array}$ & - \\
\hline PR144 & & & & & $\begin{array}{l}0.1413 \\
(0.57)\end{array}$ & \\
\hline $\mathrm{I}_{(\mathrm{Aa} 1, \mathrm{Aa} 3)}$ & $\begin{array}{l}0.0520 \\
(0.76)\end{array}$ & $\begin{array}{l}0.0271 \\
(0.90)\end{array}$ & $\begin{array}{l}0.0240 \\
(0.90)\end{array}$ & $\begin{array}{l}0.1443 \\
(0.48)\end{array}$ & $\begin{array}{l}0.2139 \\
(0.37)\end{array}$ & $\begin{array}{l}0.3541 \\
(0.21)\end{array}$ \\
\hline $\mathrm{I}_{(\mathrm{A} 1, \mathrm{~A} 3)}$ & $\begin{array}{l}0.2989 * * \\
(0.00)\end{array}$ & $\begin{array}{l}0.3389 * * \\
(0.00)\end{array}$ & $\begin{array}{l}0.3390 * * \\
(0.00)\end{array}$ & $\begin{array}{l}0.5697 * * \\
(0.00)\end{array}$ & $\begin{array}{l}0.6286 * * \\
(0.00)\end{array}$ & $\begin{array}{l}0.8114 * * \\
(0.00)\end{array}$ \\
\hline $\mathrm{I}_{\text {(Baa1, Baa3) }}$ & $\begin{array}{l}0.5720 * * \\
(0.00)\end{array}$ & $\begin{array}{l}0.6313 * * \\
(0.00)\end{array}$ & $\begin{array}{l}0.6287 * * \\
(0.00)\end{array}$ & $\begin{array}{l}0.8033 * * \\
(0.00)\end{array}$ & $\begin{array}{l}0.8516 * * \\
(0.00)\end{array}$ & $\begin{array}{l}1.1530 * * \\
(0.00)\end{array}$ \\
\hline $\mathrm{I}_{(\mathrm{Ba} 1, \mathrm{Ba} 3)}$ & $\begin{array}{l}2.2524 * * \\
(0.00)\end{array}$ & $\begin{array}{l}2.1615 * * \\
(0.00)\end{array}$ & $\begin{array}{l}2.5137 * * \\
(0.00)\end{array}$ & $\begin{array}{l}2.3062 * * \\
(0.00)\end{array}$ & $\begin{array}{l}2.3536 * * \\
(0.00)\end{array}$ & $\begin{array}{l}2.6799 * * \\
(0.00)\end{array}$ \\
\hline $\mathrm{I}_{(\mathrm{B} 1, \mathrm{Caa})}$ & $\begin{array}{l}3.6663 * * \\
(0.00)\end{array}$ & $\begin{array}{l}3.5644 * * \\
(0.00)\end{array}$ & $\begin{array}{l}3.8820 * * \\
(0.00)\end{array}$ & $\begin{array}{l}3.7090 * * \\
(0.00)\end{array}$ & $\begin{array}{l}3.7433 * * \\
(0.00)\end{array}$ & $\begin{array}{l}4.2098 * * \\
(0.00)\end{array}$ \\
\hline MAT & $\begin{array}{l}-0.0733 \\
(0.33)\end{array}$ & $\begin{array}{l}-0.0277 \\
(0.69)\end{array}$ & $\begin{array}{l}-0.0278 \\
(0.69)\end{array}$ & $\begin{array}{l}-0.0053 \\
(0.94)\end{array}$ & $\begin{array}{l}0.0002 \\
(0.99)\end{array}$ & $\begin{array}{l}0.0010 \\
(0.99)\end{array}$ \\
\hline AMT & $\begin{array}{l}-0.2567 * * \\
(0.00)\end{array}$ & $\begin{array}{l}-0.2229 * * \\
(0.00)\end{array}$ & $\begin{array}{l}-0.2408 * * \\
(0.00)\end{array}$ & $\begin{array}{l}-0.2254 * * \\
(0.00)\end{array}$ & $\begin{array}{l}-0.2182 * * \\
(0.00)\end{array}$ & $\begin{array}{l}-0.1509 \\
(0.12)\end{array}$ \\
\hline PREM & $\begin{array}{l}0.7826 * * \\
(0.02)\end{array}$ & $\begin{array}{l}0.9719 \text { ** } \\
(0.00)\end{array}$ & $\begin{array}{l}0.9161 * * \\
(0.01)\end{array}$ & $\begin{array}{l}0.9552 * * \\
(0.00)\end{array}$ & $\begin{array}{l}0.9480 * * \\
(0.00)\end{array}$ & $\begin{array}{l}0.7920 \\
(0.13)\end{array}$ \\
\hline CALL & $\begin{array}{l}0.3964 * * \\
(0.01)\end{array}$ & $\begin{array}{l}0.3908 * * \\
(0.00)\end{array}$ & $\begin{array}{l}0.3573 * * \\
(0.00)\end{array}$ & $\begin{array}{l}0.4244 * * \\
(0.00)\end{array}$ & $\begin{array}{l}0.4262 * * \\
(0.00)\end{array}$ & $\begin{array}{l}0.3327 * \\
(0.05)\end{array}$ \\
\hline SUB & $\begin{array}{l}0.5350 \\
(0.13)\end{array}$ & $\begin{array}{l}0.5713 \\
(0.12)\end{array}$ & $\begin{array}{l}0.6077 \\
(0.12)\end{array}$ & $\begin{array}{l}0.5490 \\
(0.13)\end{array}$ & $\begin{array}{l}0.5515 \\
(0.13)\end{array}$ & $\begin{array}{l}-1.6870 * * \\
(0.00)\end{array}$ \\
\hline
\end{tabular}


William Davidson Institute Working Paper 445

\begin{tabular}{|c|c|c|c|c|c|c|}
\hline \multicolumn{2}{|c|}{ Table III continued } & $\begin{array}{c}\text { Model } 1 \\
\text { Full Sample }\end{array}$ & $\begin{array}{c}\text { Model } 2 \\
\text { Full Sample }\end{array}$ & $\begin{array}{c}\text { Model } 3 \\
\text { Full Sample }\end{array}$ & $\begin{array}{c}\text { Model } 4 \\
\text { Full Sample }\end{array}$ & $\begin{array}{c}\text { Model } 5 \\
\text { Excluding } \\
\text { Canada } \\
\end{array}$ \\
\hline SINK & $\begin{array}{l}0.7543 * * \\
(0.00)\end{array}$ & $\begin{array}{l}0.6672 * * \\
(0.00)\end{array}$ & $\begin{array}{l}0.5906 * * \\
(0.01)\end{array}$ & $\begin{array}{l}0.6221 * * \\
(0.01)\end{array}$ & $\begin{array}{l}0.6218 * * \\
(0.01)\end{array}$ & $\begin{array}{l}3.7208 * * \\
(0.00)\end{array}$ \\
\hline FX & $\begin{array}{l}41.00 * * \\
(0.04)\end{array}$ & $\begin{array}{l}36.91 * \\
(0.05)\end{array}$ & $\begin{array}{l}35.92 * \\
(0.06)\end{array}$ & $\begin{array}{l}43.25 * * \\
(0.03)\end{array}$ & $\begin{array}{l}42.68 * * \\
(0.03)\end{array}$ & $\begin{array}{l}49.06 \\
(0.13)\end{array}$ \\
\hline UTL & $\begin{array}{l}-0.0877 \\
(0.38)\end{array}$ & $\begin{array}{l}-0.0843 \\
(0.38)\end{array}$ & $\begin{array}{l}-0.0984 \\
(0.31)\end{array}$ & $\begin{array}{l}-0.0487 \\
(0.60)\end{array}$ & $\begin{array}{l}-0.0361 \\
(0.71)\end{array}$ & $\begin{array}{l}-0.1271 \\
(0.55)\end{array}$ \\
\hline $\mathrm{N}$ & 260 & 260 & 260 & 260 & 260 & 109 \\
\hline $\operatorname{Adj} R^{2}$ & 0.813 & 0.827 & 0.832 & 0.834 & 0.833 & 0.850 \\
\hline
\end{tabular}




\section{Table IV}

\section{Sample Characteristics for 90 Yankee Bond Offerings, 1988-1998}

Yankee bond offerings are defined as public, straight debt securities issued by non-U.S. firms in the United States. Sample statistics are obtained from Securities Data Company, Lexis-Nexis, and Datastream.

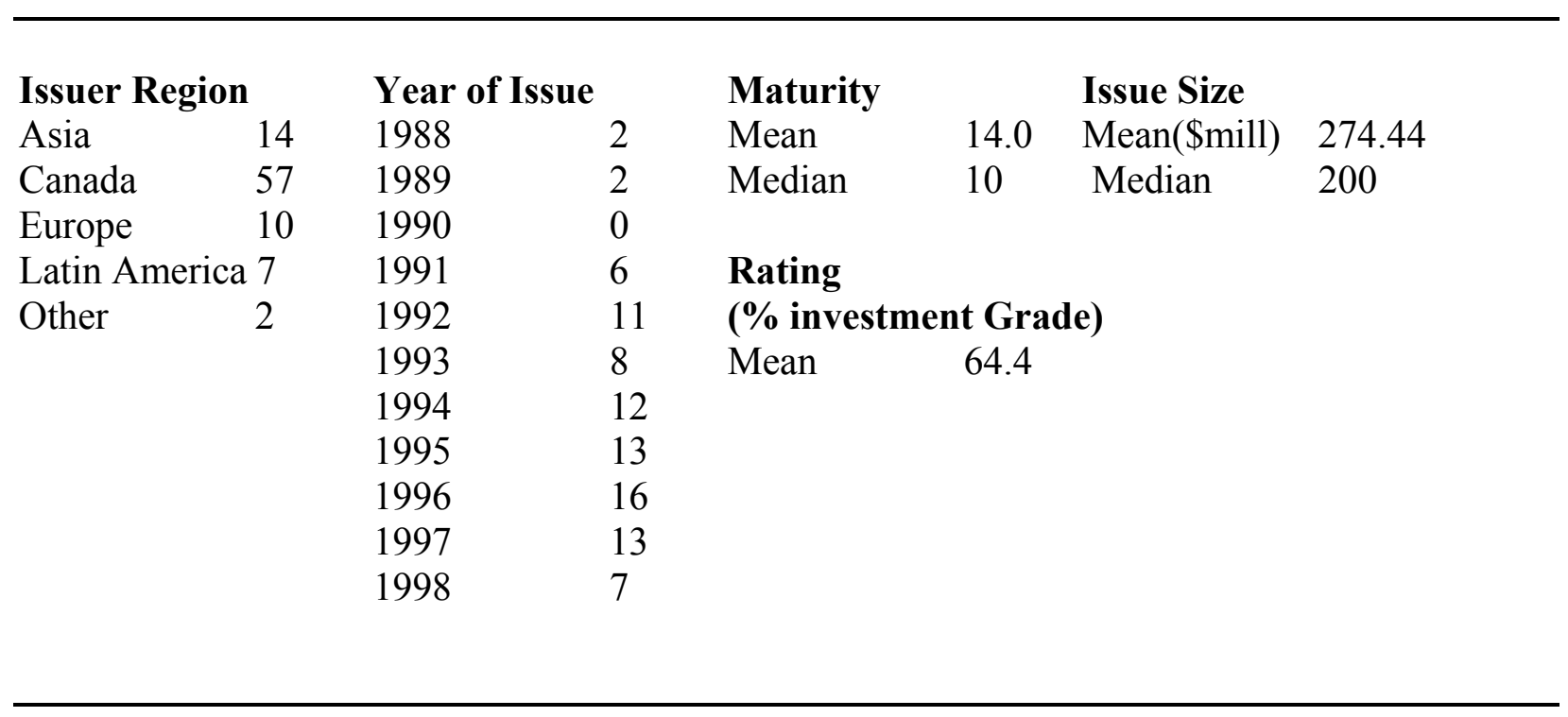




\section{Table V \\ Percent three-day average abnormal returns around the announcement of 90 Yankee bond offerings.}

Abnormal returns are market model adjusted using parameters estimated over a 125 day prelisting period, from day -150 to -26 relative to the announcement of date. A national stock market index in each country is used as a proxy for the market portfolio. The sample period is 1988 to $1998 .{ }^{*}, * *$ and $* * *$ indicate significance of the $t$-statistic at the $0.1,0.05$ and 0.01 levels, respectively.

\begin{tabular}{|c|c|c|c|}
\hline \multicolumn{4}{|l|}{ Sample } \\
\hline Classification $(\mathrm{N})$ & $\mathrm{t}=-25$ to -2 & $\mathrm{t}=-1$ to +1 & $\mathrm{t}=+2$ to +25 \\
\hline \multicolumn{4}{|c|}{ Panel A: Full Sample } \\
\hline Full Sample (90) & $-0.70 \%$ & $0.80 \%{ }^{* * *}$ & $-0.48 \%$ \\
\hline \multicolumn{4}{|c|}{ Panel B: First-time Issuers } \\
\hline Previous Issue(67) & $-0.19 \%$ & $0.56 \% * *$ & $-0.33 \%$ \\
\hline First-time Issue (23) & $-2.17 \%$ & $1.52 \% * *$ & $-0.92 \%$ \\
\hline \multicolumn{4}{|c|}{ Panel C: Geographical location } \\
\hline Developed (73) & $-0.77 \%$ & $0.63 \% * *$ & $-0.27 \%$ \\
\hline Emerging (17) & $-0.39 \%$ & $1.54 \% * *$ & $-1.39 \% *$ \\
\hline Canada (57) & $-0.52 \%$ & $0.46 \% *$ & $-0.36 \%$ \\
\hline Non-Canada (33) & $-1.01 \%$ & $1.40 \% * *$ & $-0.70 \%$ \\
\hline
\end{tabular}




\section{Table VI}

\section{Structural form estimates of the Yankee-Eurodollar bond selection equation}

Probit estimates of bond type $(1=$ Yankee, $0=$ Eurodollar $)$ on bond characteristics, information proxies, legal variables, market conditions, and the estimated interest cost differential between issuing in the Yankee and Eurodollar market. $\quad P$-values are in parentheses. ${ }^{*}$ and $* *$ indicate significance at the 0.1 and 0.05 levels, respectively.

\begin{tabular}{|c|c|c|}
\hline & Coefficient Estimate & Marginal Probabilities \\
\hline Constant & $\begin{array}{l}-2.1905 \\
(0.41)\end{array}$ & \\
\hline $\operatorname{Ln} Y_{\text {euro }}-\operatorname{Ln} Y_{\text {yankee }}$ & $\begin{array}{l}16.2533^{* *} \\
(0.00)\end{array}$ & 1.7050 \\
\hline PRUS & $\begin{array}{l}0.9180^{* *} \\
(0.01)\end{array}$ & 0.1005 \\
\hline ACCT & $\begin{array}{l}0.0869 * * \\
(0.03)\end{array}$ & 0.0091 \\
\hline CR & $\begin{array}{l}-2.1252^{* *} \\
(0.00)\end{array}$ & -0.2229 \\
\hline ROL & $\begin{array}{l}-1.3598^{* *} \\
(0.00)\end{array}$ & -0.1426 \\
\hline $\mathrm{I}_{(\mathrm{Aa} 1, \mathrm{Aa} 3)}$ & $\begin{array}{l}3.6299^{* *} \\
(0.00)\end{array}$ & 0.2410 \\
\hline $\mathrm{I}_{(\mathrm{Al}, \mathrm{A} 3)}$ & $\begin{array}{l}3.0033^{* *} \\
(0.00)\end{array}$ & 0.2126 \\
\hline $\mathrm{I}_{\text {(Baal, Ba3) }}$ & $\begin{array}{l}5.4928^{* *} \\
(0.03)\end{array}$ & 0.4492 \\
\hline MAT & $\begin{array}{l}10.1222 * * \\
(0.00)\end{array}$ & 1.0618 \\
\hline AMT & $\begin{array}{l}-2.6168^{* *} \\
(0.00)\end{array}$ & -0.2745 \\
\hline YNK SPD & $\begin{array}{l}0.1714 \\
(0.86)\end{array}$ & 0.0180 \\
\hline
\end{tabular}


Total Public Debt, 144A debt and Public Equity issued by non-US firms in the US

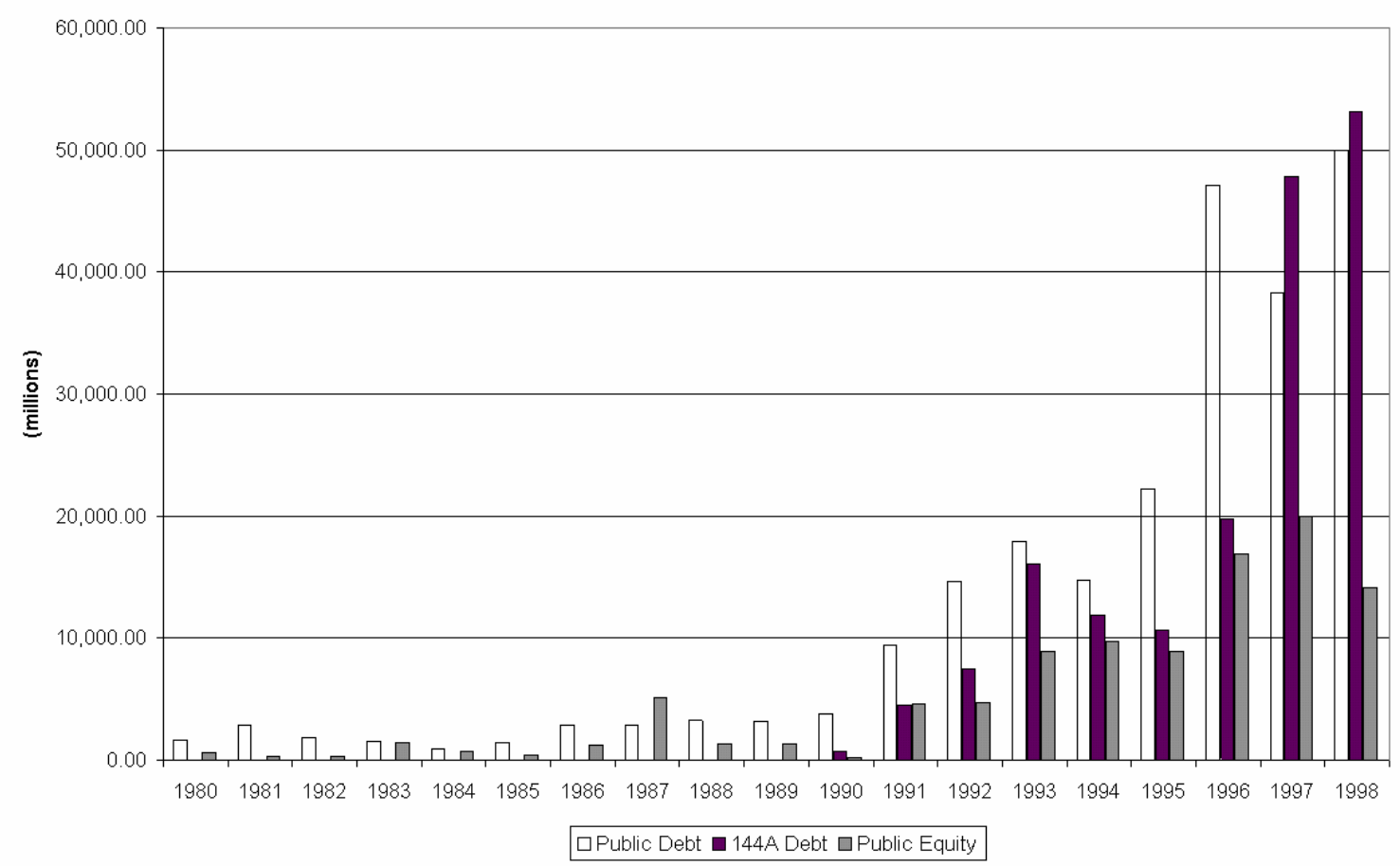

Fig. 1. Capital Raised in the U.S. by Foreign Firms, 1980-1998

This chart presents total public debt, 144A debt and public equity issued in the U.S. market by non-U.S. firms. The data is for non-U.S. financials, industrials and utilities in the U.S. market. It excludes U.S. and Supranational issuers as well as issuers with U.S. parents. Data source is the New Issues database of Securities Data Company. 
Total Public Debt raised by non-US firms

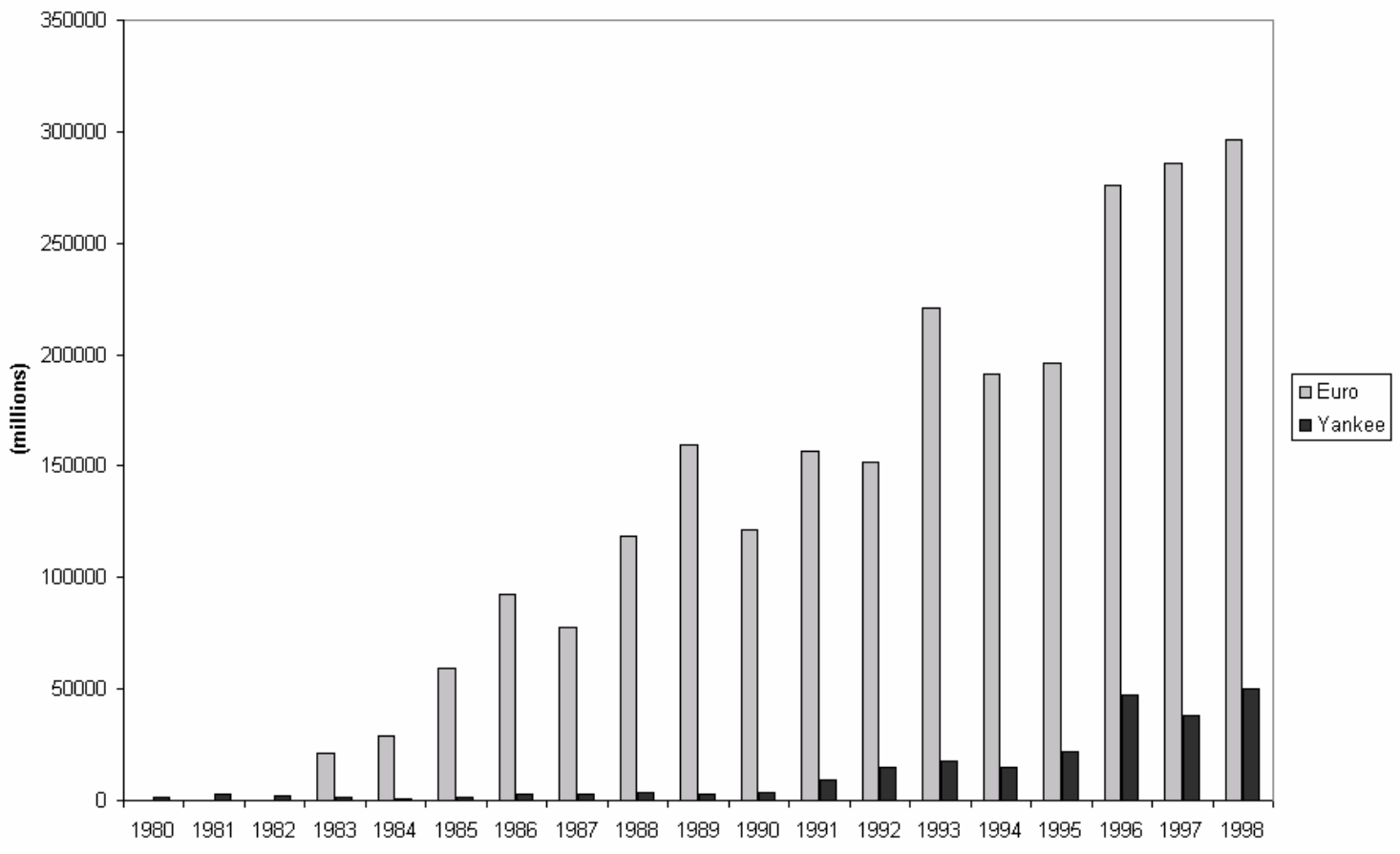

Fig. 2. Comparison of Capital Raised by Foreign Firms in the Yankee and Euro markets, 1980-1998.

This chart presents total public debt issued in the U.S. and Euro markets by non-U.S. firms. The data is for non-U.S. financials, industrials and utilities. It excludes U.S. and Supranational issuers as well as issuers with U.S. parents. Data source is the New Issues database of Securities Data Company. 


\section{DAVIDSON INSTITUTE WORKING PAPER SERIES - Most Recent Papers}

The entire Working Paper Series may be downloaded free of charge at: www.wdi.bus.umich.edu

CURRENT AS OF 3/7/02

\begin{tabular}{|c|c|c|}
\hline Publication & Authors & Date \\
\hline No. 444: Financial Institutions, Contagious Risks, and Financial Crises & $\begin{array}{l}\text { Haizhou Huang and Chenggang } \\
\mathrm{Xu}\end{array}$ & Nov. 2001 \\
\hline No. 443: Banks as Catalysts for Industrialization & $\begin{array}{l}\text { Marco Da Rin and Thomas } \\
\text { Hellman }\end{array}$ & Oct. 2001 \\
\hline $\begin{array}{l}\text { No. 442: Bank-Based or Market-Based Financial Systems: Which is } \\
\text { Better? }\end{array}$ & Ross Levine & Feb. 2002 \\
\hline $\begin{array}{l}\text { No. 441: Migration and Regional Adjustment and Asymmetric Shocks } \\
\text { in Transition Economies }\end{array}$ & Jan Fidrmuc & Feb. 2002 \\
\hline $\begin{array}{l}\text { No. 440: Employment and Wages in Enterprises Under Communism } \\
\text { and in Transition: Evidence From Central Europe and Russia }\end{array}$ & $\begin{array}{l}\text { Swati Basu, Saul Estrin, and Jan } \\
\text { Svejnar }\end{array}$ & June 2000 \\
\hline No. 439: Small business in Russia: A Case Study of St. Petersburg & Alessandro Kihlgren & Jan. 2002 \\
\hline $\begin{array}{l}\text { No. 438: Foreign Direct Investment as Technology Transferred: } \\
\text { Some Panel Evidence from the Transition Economies }\end{array}$ & $\begin{array}{l}\text { Nauro F. Campos and Yuko } \\
\text { Kinoshita }\end{array}$ & Jan. 2002 \\
\hline No. 437: Whistleblowing, MNC's and Peace & Terry Morehead Dworkin & Feb. 2002 \\
\hline $\begin{array}{l}\text { No. 436: A Note on Measuring the Unofficial Economy in the Former } \\
\text { Soviet Republics }\end{array}$ & $\begin{array}{l}\text { Michael Alexeev and William } \\
\text { Pyle }\end{array}$ & Sept. 2001 \\
\hline $\begin{array}{l}\text { No. 435: The Ownership School vs. the Management School of State } \\
\text { Enterprise Reform: Evidence from China }\end{array}$ & David D. Li and Changqi Wu & Jan. 2002 \\
\hline $\begin{array}{l}\text { No. 434: The Effect of Ownership and Competitive Pressure on Firm } \\
\text { Performance in Transition Countries: Micro Evidence from Bulgaria, } \\
\text { Romania and Poland. }\end{array}$ & $\begin{array}{l}\text { Manuela Angelucci, Saul Estrin, } \\
\text { Jozef Konings, Zbigniew } \\
\text { Zolkiewski }\end{array}$ & Jan. 2002 \\
\hline No. 433: The End of Moderate Inflation in Three Transition Economies? & Josef C. Brada and Ali M. Kutan & Jan. 2002 \\
\hline $\begin{array}{l}\text { No. 432: What Drives the Speed of Job Reallocation During Episodes of } \\
\text { Massive Adjustment? }\end{array}$ & $\begin{array}{l}\text { Stepan Jurajc } \\
\text { Terrell }\end{array}$ & Jan. 2002 \\
\hline $\begin{array}{l}\text { No. } 431 \text { Forthcoming in: The Journal of Economic Perspectives, } \\
\text { "Competition and Corporate Governance in Transition," 16(2) Feb. } \\
2002 .\end{array}$ & Saul Estrin & 2001 \\
\hline $\begin{array}{l}\text { No. 430: Corporate Governance in the Cause of Peace: An } \\
\text { Environmental Perspective }\end{array}$ & Mayer & Jan. 2002 \\
\hline No. 429: Why do Governments Privatize? & $\begin{array}{l}\text { Loren Brandt, Hongbin Li, and } \\
\text { Joanne Roberts }\end{array}$ & Dec. 2001 \\
\hline No. 428: Testing Russia's Virtual Economy & Vlad Ivanenko & Dec. 2001 \\
\hline No. 427: War and the Business Corporation & Eric W. Orts & Dec. 2001 \\
\hline $\begin{array}{l}\text { No. 426: Partial Privatization and Firm Performance: Evidence from } \\
\text { India }\end{array}$ & Nandini Gupta & Dec. 2001 \\
\hline $\begin{array}{l}\text { No. 425: Direct Foreign Investments and Productivity Growth in } \\
\text { Hungarian Firms, 1992-1999 }\end{array}$ & Jérôme Sgard & Nov. 2001 \\
\hline $\begin{array}{l}\text { No. 424: Banking Passivity and Regulatory Failure in Emerging } \\
\text { Markets: Theory and Evidence from the Czech republic. }\end{array}$ & Jan Hanousek and Gerard Roland & July 2001 \\
\hline $\begin{array}{l}\text { No. 423: Conceptions of the Corporation and the Prospects of } \\
\text { Sustainable Peace }\end{array}$ & Jeffrey Nesteruk & Dec. 2001 \\
\hline No. 422: The Role of the Corporation in Fostering Sustainable Peace & Timothy Fort and Cindy Schipani & Nov. 2001 \\
\hline No. 421: Wage Arrears and the Distribution of Earnings in Russia & $\begin{array}{l}\text { Hartmut Lehmann and Jonathan } \\
\text { Wadsworth }\end{array}$ & Dec. 2001 \\
\hline $\begin{array}{l}\text { No. 420: Transferring Collective Knowledge: Collective and } \\
\text { Fragmented Teaching and Learning in the Chinese Auto Industry }\end{array}$ & $\begin{array}{l}\text { Jane Zhou, Jaideep Anand, and } \\
\text { Will Mitchell }\end{array}$ & Dec. 2001 \\
\hline $\begin{array}{l}\text { No. 419: Liberalization, Corporate Governance, and the Performance of } \\
\text { Newly Privatized Firms }\end{array}$ & $\begin{array}{l}\text { Narjess Boubakri, Jean-Claude } \\
\text { Cosset, and Omrane Guedhami }\end{array}$ & Dec. 2001 \\
\hline
\end{tabular}

